Marquette University

e-Publications@Marquette

Biomedical Sciences Faculty Research and

Publications

Biomedical Sciences, Department of

3-2017

\title{
Combined Chondroitinase and KLF7 Expression Reduce Net Retraction of Sensory and CST Axons from Sites of Spinal Injury
}

Zimei Wang

Marquette University

Kristen N. Winsor

Marquette University

Evan Hess

Marquette University

Murray G. Blackmore

Marquette University, murray.blackmore@marquette.edu

Christopher Nienhaus

Marquette University

Follow this and additional works at: https://epublications.marquette.edu/biomedsci_fac

Part of the Neurosciences Commons

\section{Recommended Citation}

Wang, Zimei; Winsor, Kristen N.; Hess, Evan; Blackmore, Murray G.; and Nienhaus, Christopher, "Combined Chondroitinase and KLF7 Expression Reduce Net Retraction of Sensory and CST Axons from Sites of Spinal Injury" (2017). Biomedical Sciences Faculty Research and Publications. 162.

https://epublications.marquette.edu/biomedsci_fac/162 


\title{
Combined Chondroitinase and KLF7 Expression Reduce Net Retraction of Sensory and CST Axons from Sites of Spinal Injury
}

\author{
Zimei Wang \\ Department of Biomedical Sciences, Marquette University \\ Milwaukee, WI \\ Kristen Winsor \\ Department of Biomedical Sciences, Marquette University \\ Milwaukee, WI \\ Christopher Nienhaus \\ Department of Biomedical Sciences, Marquette University \\ Milwaukee, WI \\ Evan Hess \\ Department of Biomedical Sciences, Marquette University \\ Milwaukee, WI \\ Murray G. Blackmore \\ Department of Biomedical Sciences, Marquette University \\ Milwaukee, WI
}

Neurobiology of Disease, Vol. 99 (March 2017): pg. 24-35. DOI. This article is @ Elsevier and permission has been granted for this version to appear in e-Publications@Marquette. Elsevier does not grant permission for this article to be further copied/distributed or hosted elsewhere without the express permission from Elsevier. 
NOT THE PUBLISHED VERSION; this is the author's final, peer-reviewed manuscript. The published version may be accessed by following the link in the citation at the bottom of the page.

Abstract: Axon regeneration in the central nervous system is limited both by inhibitory extracellular cues and by an intrinsically low capacity for axon growth in some CNS populations. Chondroitin sulfate proteoglycans (CSPGs) are well-studied inhibitors of axon growth in the CNS, and degradation of CSPGs by chondroitinase has been shown to improve the extension of injured axons. Alternatively, axon growth can be improved by targeting the neuron-intrinsic growth capacity through forced expression of regeneration-associated transcription factors. For example, a transcriptionally active chimera of Krüppel-like Factor 7 (KLF7) and a VP16 domain improves axon growth when expressed in corticospinal tract neurons. Here we tested the hypothesis that combined expression of chondroitinase and VP16-KLF7 would lead to further improvements in axon growth after spinal injury. Chondroitinase was expressed by viral transduction of cells in the spinal cord, while VP16-KLF7 was virally expressed in sensory neurons of the dorsal root ganglia or corticospinal tract (CST) neurons. After transection of the dorsal columns, both chondroitinase and VP16-KLF7 increased the proximity of severed sensory axons to the injury site. Similarly, after complete crush injuries, VP16-KLF7 expression increased the approach of CST axons to the injury site. In neither paradigm however, did single or combined treatment with chondroitinase or VP16-KLF7 enable regenerative growth distal to the injury. These results substantiate a role for CSPG inhibition and low KLF7 activity in determining the net retraction of axons from sites of spinal injury, while suggesting that additional factors act to limit a full regenerative response.

Keywords: Spinal cord injury; Axon regeneration; Corticospinal; Dorsal root ganglion; Chondroitin sulfate proteoglycan; Chondroitinase; Transcription factor; Adeno-associated virus; Lentivirus; KLF7

\section{Introduction}

Recovery from injury to the central nervous system (CNS) is limited by the inability of severed axons to regenerate and re-establish effective communication. Axon regeneration is constrained in part by cell-intrinsic mechanisms in many axotomized CNS neurons, including a failure to initiate needed pro-regenerative transcriptional programs (Blackmore, 2012; Moore and Goldberg, 2011). One well-studied example is the differential regenerative ability of the peripherally versus centrally projecting branches of sensory axons. Successful axon regeneration of the peripheral branch depends on the transcription of regeneration associated genes (RAGs) in the sensory cell body (Smith and Skene, 1997), which in turn depends on transcription factors that are themselves upregulated or activated in response to peripheral axotomy (Ben-Yaakov et al., 2012; Broude et al., 1997; Jankowski et al., 2009; Michaelevski et al., 2010; Tsujino et al., 2000). In contrast, injury to the centrally projecting axon triggers RAG expression that is smaller in magnitude and shorter in duration (Broude et al., 1997; Geeven et al., 2011; Ma and Willis, 2015; Stam et al., 2007). In the same way, many CNS neurons respond to axotomy with modest and/or transient RAG expression (Chaisuksunt et al., 2000). This failure of RAG expression appears particularly acute in the case of corticospinal tract (CST) neurons after spinal axotomy (Mason et al., 2003), and likely contributes to the relatively modest CST response to a wide range of attempted pro-regenerative therapies (Hollis et al., 2009; Lee et al., 2010b; Pearse et al., 2004; Richardson et al., 1984).

Neurobiology of Disease, Vol. 99 (March 2017): pg. 24-35. DOI. This article is @ Elsevier and permission has been granted for this version to appear in e-Publications@Marquette. Elsevier does not grant permission for this article to be further copied/distributed or hosted elsewhere without the express permission from Elsevier. 
These observations have led to the hypothesis that regeneration by central DRG axons and/or CNS axons might be improved by forced expression of RAGs, particularly key transcription factors that may orchestrate regenerative gene expression (Ma and Willis, 2015; van Kesteren et al., 2011). For example, Krüppel-like factor 7 is a pro-regenerative transcription factor that is normally expressed in peripheral neurons and in CNS neurons during embryonic periods of axon growth, but downregulated in the adult CNS (Laub et al., 2001). We have shown previously that forced expression of a transcriptionally active form, VP16-KLF7, improves axon growth in adult CST neurons after spinal injury (Blackmore et al., 2012). The degree of axon regeneration remains incomplete, however, highlighting the need to identify and overcome additional mechanisms that limit CNS axon growth.

Besides neuron-intrinsic limits, regeneration by CNS axons is also constrained by inhibitory extracellular cues. Prominent among these are chondroitin sulfate proteoglycans (CSPGs), which are produced at high levels by oligodendrocytes and reactive astrocytes near sites of CNS injury (Asher et al., 2002; Jones et al., 2003; Jones et al., 2002; Silver and Miller, 2004). CSPGs consist of a protein core adorned with sulphated glycosoaminoglycan (GAG) side chains (Bandtlow and Zimmermann, 2000), and inhibit axon extension in a

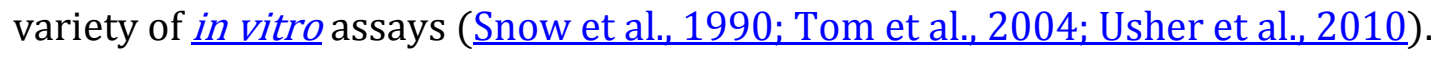
Chondroitinase, a bacterial enzyme that cleaves GAG side chains, has been shown repeatedly to reduce CSPG's inhibitory properties in vitro (Niederost et al., 1999; Snow et al., 1990; Yamada et al., 1997), and to promote axon growth in vivo after spinal injury (Bartus et al., 2012; Bradbury et al., 2002; Cheng et al., 2015; Iseda et al., 2008). Thus chondroitinase-mediated degradation of CSPGs has emerged as an important component of combinatorial treatments to promote axon regeneration (Hunanyan et al., 2013; Kanno et al., 2014; Lee et al., 2013; Steinmetz et al., 2005; Tom et al., 2009; Tropea et al., 2003).

Here we tested the hypothesis that combined expression of VP16-KLF7 and application of chondroitinase can improve axon growth in the injured spinal cord. Based on previously developed and validated vectors, we created lentivirus to drive expression of chondroitinase optimized for mammalian expression and thermal stability (Muir et al., 2010; Nazari-Robati et al., 2013; Zhao et al., 2011). VP16-KLF7 was delivered by adenoassociated virus to sensory neurons in dorsal root ganglia, or in separate experiments, to cortical neurons. Spinally projecting axons were injured by transection or crush injury, and axon regeneration was assessed in the presence or absence of lentiviral chondroitinase. In DRG neurons, VP16-KLF7 expression increased the proximity of injured axons to the site of transection injury, but in contrast to previous findings in CST axons responding to a similar partial injury, did not evoke robust growth through spared tissue. Similarly, in CST neurons responding to complete spinal crush, forced expression of VP16-KLF7 increased proximity

Neurobiology of Disease, Vol. 99 (March 2017): pg. 24-35. DOI. This article is @ Elsevier and permission has been granted for this version to appear in e-Publications@Marquette. Elsevier does not grant permission for this article to be further copied/distributed or hosted elsewhere without the express permission from Elsevier. 
to the injury site but not growth distal to the injury. Chondroitinase treatment also increased the approach of injured DRG axons to the injury center but not extension beyond the injury. In neither DRG nor CST neurons did chondroitinase significantly potentiate the effects of VP16-KLF7 expression. These results demonstrate regulation of net retraction from injury sites by KLF7 transcription and CSPGs, while highlighting the existence of additional constraints to full axon growth.

\section{Methods}

\subsection{Cloning of KLF7 and lenti-chondroitinase}

DNA encoding $P$. vulgaris chondroitinase ABC (accession number AAB43331) with a $5^{\prime}$ signal sequence from matrix metalloprotease two (MMP2, accession NM008610) and codon optimized for mammalian expression was synthesized by Genscript. The construct included N282K, N338Q, N345Q, and S517A mutations, previously shown to block inappropriate $\mathrm{N}$-glycosylation (Muir et al., 2010; Zhao et al., 2011), as well as Q140A, shown previously to increase thermostability (Nazari-Robati et al., 2013). Chondroitinase was cloned into Lenti-MP2 vector, supplied by the University of Miami Viral Vector Core, which produced Lenti-Chase. AAV8-VP16-KLF7-2A-mCherry, AAV-EBFP-2A-mCherry, and AAV8-EGFP were cloned and produced by the Univ. of Miami Viral Core as described previously in (Blackmore et al., 2012).

\subsection{Plasmid transfection of $293 \mathrm{~T}$ cells and enzyme assay}

293T cells (ATCC) were plated at 90\% confluency in 6 well plates (Cellstar) and transfected with Lenti-Chase or EGFP control plasmid using Lipofectamine 2000 (Invitrogen) according to the manufacturer's instructions with $2.4 \mu \mathrm{g}$ DNA and $3 \mu \mathrm{l}$ Lipofectamine per well. After two days of culture at $37^{\circ} \mathrm{C}$ in a $5 \% \mathrm{CO} 2$ incubator in $2 \mathrm{ml}$ Optimem media (Gibco), media was collected for chondroitinase activity measurement. The Proteoglycan Detection Kit (Amsbio com) quantifies sulfated glycoaminoglycans using 1,9-dimethylmethylene (DMMB) dye, which shifts it's absorption spectrum upon GAG binding. To generate a standard curve of chondroitinase activity, $0.5 \mu \mathrm{g}$ of CSPGs (Millipore) were incubated with chondroitinase enzyme (Amsbio) at 0, 12.5, 25, 50, and $100 \mathrm{mU} / \mathrm{ml}$ for $2 \mathrm{~h}$ at $37^{\circ} \mathrm{C}$, exposed briefly to DMMB, and then $525 \mathrm{nM}$ absorbance as quantified by microplate reader (Molecular Devices). To quantify chondroitinase activity generated by transfected cells, $0.5 \mu \mathrm{g}$ of CSPGs were incubated with a 1:1000 dilution of

Neurobiology of Disease, Vol. 99 (March 2017): pg. 24-35. DOI. This article is (C) Elsevier and permission has been granted for this version to appear in e-Publications@Marquette. Elsevier does not grant permission for this article to be further copied/distributed or hosted elsewhere without the express permission from Elsevier. 
NOT THE PUBLISHED VERSION; this is the author's final, peer-reviewed manuscript. The published version may be accessed by following the link in the citation at the bottom of the page.

conditioned media from 293T cells transfected or transduced with chondroitinase constructs or mCherry control. All test and standard curve controls were run in duplicate.

\subsection{DRG cell culture, transfection, and neurite outgrowth}

24-well plates were prepared for cell culture by overnight incubation with PDL (100 $\mathrm{\mu g} / \mathrm{ml}$, Sigma) followed by extensive rinsing with water. Wells were then incubated overnight at $37^{\circ} \mathrm{C}$ with laminin alone $(10 \mu \mathrm{g} / \mathrm{ml}$, Sigma) or with a mixture of laminin and controlled amounts of CSPGs (0.5 to $5 \mu \mathrm{g} / \mathrm{ml}$; Millipore). Dorsal root ganglia were dissected from adult mice and dissociated by incubation with Collagenase Type $1(0.5 \mathrm{mg} / \mathrm{ml}$, Invitrogen), Dispase (10 mg/ml, Invitrogen) and DNAse I $(2.5 \mu \mathrm{g} / \mathrm{ml}$, Sigma $)$ at $37^{\circ} \mathrm{C}$ for $40 \mathrm{~min}$, followed by trituration with a fire-polished pipette in $1 \mathrm{ml}$ Hibernate $\mathrm{E}$ (Gibco). Cells were rinsed in $5 \mathrm{ml}$ Hibernate E, pelleted by centrifugation at 20G for $10 \mathrm{~min}$, and resuspended in DMEM: F12 media (Gibco) supplemented with SM1 (StemCell Technologies), Pen Strep (Gibco), and Glutamax (Thermofisher) for cell counting. Cells were transfected with VP16KLF7-2A-mCherry or EBFP-2A-mCherry control by electroporation in a Nucleofector II interfaced with a Lonza 96-well Shuttle. 20,000 cells were placed in each transfection well with $20 \mu \mathrm{l}$ P3 buffer (Lonza), mixed with $1.6 \mu \mathrm{g}$ DNA, and current was delivered by program DR-114. Following transfection, $80 \mu \mathrm{l}$ of DRG culture media was immediately added. DRG neurons were cultured in the prepared 24-well plates at a density of 4000 cells per well.

After $48 \mathrm{~h}$, cells were fixed in 4\% paraformaldehyde (Electron Microscopy Sciences) for $30 \mathrm{~min}$, rinsed in PBS, transferred to a blocking solution 20\% goat serum (Invitrogen), $0.2 \%$ Triton X-100 (G-Biosciences) for $30 \mathrm{~min}$, incubated overnight at $4{ }^{\circ} \mathrm{C}$ with neuronal specific tubulin rabbit polyclonal antibody (1:500, Sigma T2200), followed by secondary Goat-anti-Rabbit AlexaFluorß546 conjugated antibody (1:500, Invitrogen) and $300 \mathrm{nM}$ DAPI nuclear stain (Sigma) for $2 \mathrm{~h}$ at room temperature. To quantify neurite outgrowth, neurons were visualized using an inverted Olympus IX81 fluorescence microscope interfaced with a Coolsnap ES2 digital camera (Photometrics). Transfected neurons were identified by mCherry fluorescence, and the longest neurite from each transfected cells was manually traced using NIS Elements Software.

\subsection{Viral delivery to DRG and cortical neurons}

AAV8-EBFP-2A-mCherry or AAV8-VP16KLF7-2A-mCherry were delivered to sensory neurons by lumbar puncture as described in (Vulchanova et al., 2010 (Wang et al., 2015)). Briefly, a $30 \mathrm{G}$ needle attached by PE10 tubing to a $10 \mu \mathrm{l}$ Hamilton syringe was

Neurobiology of Disease, Vol. 99 (March 2017): pg. 24-35. DOI. This article is @ Elsevier and permission has been granted for this version to appear in e-Publications@Marquette. Elsevier does not grant permission for this article to be further copied/distributed or hosted elsewhere without the express permission from Elsevier. 
inserted at the midline at the level of the iliac crest, into the spinal column until a characteristic tail flick indicated entry into intrathecal space. $1.5 \mu \mathrm{l}$ of viral particles $\left(5 \times 10^{13} \mathrm{p} / \mathrm{ml}\right)$ were injected and the needle kept in place for $30 \mathrm{~s}$ prior to removal. The procedure was performed on two consecutive days prior to spinal injury.

Cortical neurons were transduced as described in (Blackmore et al., 2012; Wang et al., 2015). Briefly, adult mice (>8 wks, 20-22 g) were anesthetized by Ketamine/Xylazine $(100 / 10 \mathrm{mg} / \mathrm{kg}$, IP), mounted in a stereotaxic frame, and targeted regions of cortex exposed by scraping away skull with a scalpel blade. A pulled glass micropipette attached to a $10 \mu$ l Hamilton syringe driven by a programmable pump (Stoelting qsi) was used to deliver $0.5 \mu \mathrm{l}$ of viral particles $\left(5 \times 10^{13} \mathrm{p} / \mathrm{ml}\right)$ at a rate of $0.05 \mu \mathrm{l} / \mathrm{min}$ to two sites, located $0.5 \mathrm{~mm}$ anterior and $-1.3 \mathrm{~mm}$ lateral from Bregma, at a depth of $0.55 \mathrm{~mm}$. The needle was left in place for $1 \mathrm{~min}$ after each injection to minimize upward flow of viral solution.

\subsection{Pyramidotomy, spinal injuries and injections}

To perform cervical dorsal hemisections, adult female C57/Bl6 mice ( $>8$ wks age, 20-22 g) were anesthetized by Ketamine/Xylazine, the cervical spinal column exposed by incision of the skin and blunt dissection of muscles, and mounted in a custom spine stabilizer. Using a Vibraknife device (Zhang et al., 2004), in which a rapidly vibrating blade is controlled via a micromanipulator, a transection was made between the 4 th and 5 th cervical vertebrae, extending from the midline to beyond the right lateral edge of the spinal cord, to a depth of $0.85 \mathrm{~mm}$. The blade was withdrawn, the overlying muscles sutured, and the wound closed with wound clips.

Unilateral pyramidotomy was performed as described in (Blackmore et al., 2012; Wang et al., 2015). Briefly, a ventral midline incision was made to expose the occipital bone, the ventrocaudal part of which was removed using fine rongeurs. The dura was punctured and the right pyramid cut completely using a micro feather scalpel.

For thoracic crush injuries, midline incisions were made at the level of thoracic vertebrae (T5-T9) and the skin and superficial muscles were retracted. The mice underwent a T7-T9 laminectomy and then received a 15 s compression injury at the level of T8 of the spinal cord with a \#5 Dumont forceps with tip ground to a width of $0.1 \mathrm{~mm}$ and length of $5 \mathrm{~mm}$. Next, a piece of sterile absorbable gelatin sponge (Gelfoam, Pfizer Inc.) was placed over the dura between T7-T9 and finally, muscles and skin were sutured.

Neurobiology of Disease, Vol. 99 (March 2017): pg. 24-35. DOI. This article is @ Elsevier and permission has been granted for this version to appear in e-Publications@Marquette. Elsevier does not grant permission for this article to be further copied/distributed or hosted elsewhere without the express permission from Elsevier. 
Intraparenchymal injections were performed immediately after spinal cord injury with mice mounted in the spine stabilizer. In the case of cervical hemisection injuries, C4/5 laminectomies were performed to allow access to the cord. Lenti-Chase or saline control was delivered using a pulled glass micropipette fitted to a $10 \mu \mathrm{l}$ Hamilton syringe driven by a Stoelting qui pump and guided by a micromanipulator. $0.5 \mu \mathrm{l}$ of Lenti-Chase $\left(5 \times 10^{7} \mathrm{p} / \mathrm{ml}\right)$ or saline control was injected at each of 4 sites located $0.5 \mathrm{~mm}$ rostral and caudal to the injury, $200 \mu \mathrm{m}$ lateral to the midline, and to a depth of $0.8 \mathrm{~mm}$.

\subsection{Tracing of ascending DRG axons and sciatic nerve injuries}

One week prior to sacrifice, mice underwent anterograde tracing of the ascending projection of lumber DRGs by injection of the transganglionic tracer Dextran $(10,000 \mathrm{MW})$ conjugated to Alexafluor-488 (Thermofisher) to the sciatic nerve. As described in (Wang et al., 2015), a longitudinal incision was made in the skin over the upper posterior part of the right thigh and the gluteal region. The fibers of the gluteus maximus muscle were then separated with \#5 Dumont forceps to expose the sciatic nerve. The needle tip of a glass micropipette attached to a $10 \mu$ l Hamilton syringe was inserted into the nerve and $2 \mu \mathrm{l}$ of $15 \%$ Dextran in PBS was injected into three sites distributed through the width of the nerve. After 1 min the needle was withdrawn. For sciatic nerve injuries, following the injections, \#5 Dumont forceps with tip ground to a width of $0.1 \mathrm{~mm}$ and length of $5 \mathrm{~mm}$ were closed firmly about the nerve for $10 \mathrm{~s}$. Following injection and injury, the nerve and surrounding muscles were washed with a saline soaked cotton swab, and wound was closed with wound clips.

\subsection{Tissue collection, immunohistochemistry, and WFA staining}

Eight weeks (spinal cord) or four weeks (pyramidotomy) after injury, animals were deeply anesthetized and transcardially perfused with PBS followed by $4 \%$ paraformaldehyde in PBS. Dorsal root ganglia, spinal cords, and brains were post-fixed overnight in $4 \%$ paraformaldehyde. Spinal cords were embedded in $6 \%$ gelatin and then $100 \mu \mathrm{m}$ sagittal sections prepared by vibratome (VT1200, Leica). Dorsal ganglia were embedded in 6\% gelatin and $100 \mu \mathrm{m}$ sections prepared by vibratome. $\underline{\text { Immunohistochemistry was performed on floating sections using antibodies to GFAP }}$ (Dako, 1:500), CSPG stub epitopes (2B6,amsbio, 1:300; anti-C4S clone EB-123, Millipore, 1:500) and intact CSPGs (1:500, Sigma) overnight at $4{ }^{\circ} \mathrm{C}$, followed by incubation with Alexafluor-conjugated secondary antibodies (Invitrogen) for $2 \mathrm{~h}$ at room temperature.

Neurobiology of Disease, Vol. 99 (March 2017): pg. 24-35. DOI. This article is @ Elsevier and permission has been granted for this version to appear in e-Publications@Marquette. Elsevier does not grant permission for this article to be further copied/distributed or hosted elsewhere without the express permission from Elsevier. 
Viral transduction was assessed by confocal microscopy using a Zeiss axioplane2 microscope with SPOT digital photomicroscopy capabilities, a Pulnix CCD camera and Macbased (G5) image analysis system. In the DRG regeneration experiment, transduced cells were identified by mCherry fluorescence and peripherally projecting DRG neurons were identified by Dextran-Alexafluor488 signal retrogradely transported from sciatic nerve injections. DRG axon growth in the spinal cord was assessed using an inverted Olympus IX81 fluorescence microscope and NIS Elements Software. To assess CSPG degradation, the intensities of immunoreactivity with CSPG stub epitopes (2B6 and C4S) was analyzed with an Olympus IX81 microscope. Using NIS elements software, the mean fluorescence of tissue within crush sites, as outlined by GFAP immunoreactivity, was quantified and normalized to background fluorescence.

WFA staining was modified from (Mauney et al., 2013). Vibratome sections were rinsed $5 \times$ in citric acid buffer (CAB, $0.1 \mathrm{M}$ Citric acid monohydrate, $0.2 \mathrm{M}$ dibasic sodium phosphate (Sigma)), then incubated in $\mathrm{CAB}$ at $80^{\circ} \mathrm{C}$ with cooling to room temperature for 30 min. Slices were then incubated in 1:1000 Biotinylated Wisteria floribunda Lectin (Vector Labs) in CAB with $1 \%$ BSA overnight at $4{ }^{\circ} \mathrm{C}$, rinsed $5 \times$ in $\mathrm{CAB}$, incubated $2 \mathrm{~h}$ with Alexa Fluor 488 Streptavadin (Invitrogen), and imaged with an Olympus IX81 microscope.

\subsection{Quantification of axon sprouting/retraction in vivo}

To quantify axon retraction, the lesion center in spinal section was first identified using the midpoint of elevated GFAP immunoreactivity. Then the distance between the farthest rostral extent of injured DRG axons (Dextran $488^{+}$) and the lesion center was quantified in each of four spinal cord sections that spanned the axon tract, with the minimal distance reported. Similarly, in corticospinal regeneration experiments, the distance between virally transduced $\left(\mathrm{EGFP}^{+}\right) \mathrm{CST}$ axons and edge of the thoracic spinal cord injury, as defined by the boundary of GFAP-reactive astrocytes. To quantify relative lesion sizes between groups, the area within the GFAP-positive rim was traced using an inverted Olympus IX81 fluorescence microscope and NIS Elements Software. Four sagittal sections, selected at equivalent positions within $300 \mu \mathrm{m}$ of the midline, were measured per animal and then averaged. To quantify CST sprouting after unilateral pyramidotomy, horizontal sections containing EGFP + CST axons were examined. In two adjacent sections that contained the main dorsal CST tract, a $500 \mu \mathrm{m}$ line was drawn parallel to the midline and $250 \mu \mathrm{m}$ to the right. The number of EGFP + profiles that intersected this line was quantified using an inverted Olympus IX81 fluorescence microscope and NIS Elements Software, and averaged across the two sections. Statistical analysis was paired $t$-test using Graphpad Prism Software.

Neurobiology of Disease, Vol. 99 (March 2017): pg. 24-35. DOI. This article is @ Elsevier and permission has been granted for this version to appear in e-Publications@Marquette. Elsevier does not grant permission for this article to be further copied/distributed or hosted elsewhere without the express permission from Elsevier. 
NOT THE PUBLISHED VERSION; this is the author's final, peer-reviewed manuscript. The published version may be accessed by following the link in the citation at the bottom of the page.

\section{Results}

\subsection{VP16-KLF7 expression modestly increases neurite length when pre-expressed in cultured DRG neurons}

It was shown previously that forced expression of the transcription factor KLF7, which is widely expressed in CNS and PNS neurons during development and then downregulated in most CNS neurons, increases axon lengths in cortical neurons and retinal ganglion cells in culture (Blackmore et al., 2010; Moore et al., 2009). In subsequent experiments in vivo, wildtype KLF7 delivered by AAV was found to be poorly expressed compared to a modified form in which the endogenous activation domain was replaced with a VP16 activation domain (Blackmore et al., 2012). Importantly, viral expression of VP16-KLF7 in cortical neurons enhanced the regeneration of CST axons after partial spinal injury (Blackmore et al., 2012).

Unlike cortical neurons, which strongly downregulate KLF7 during postnatal development, sensory neurons maintain basal expression of KLF7 in adulthood (Laub et al., 2001). It remains possible, however, that this expression is suboptimal for neurite growth, and we therefore tested whether forced expression of VP16-KLF7 increases neurite outgrowth in cultured DRG neurons. VP16-KLF7, rather than wildtype KFL7, was selected for study based on previous data indicating more effective expression and activity by this construct compared to wildtype (Blackmore et al., 2012). DRG neurons were dissociated from adult mice and transfected by electroporation with plasmid DNA expressing VP16KLF7 or EBFP control. All constructs included mCherry reporter expressed via a T2A peptide bridge (Blackmore et al., 2012; Wang et al., 2015). Transfected cells were cultured for two days, fixed and labeled with neuron-specific $\beta$ III tubulin, and neurite length was quantified in transfected (mCherry +) neurons. Neurite lengths were similar in VP16-KLF7 transfected and control EBFP-transfected neurons (EBFP $780.3 \mu \mathrm{m} \pm$ 30.2SEM, VP16-KLF8 $800.53 \mu \mathrm{m} \pm 22.2 \mathrm{SEM}, \mathrm{p}>0.05$, paired $t$-test). Thus, in contrast to previous findings in postnatal cortical neurons, performed with identical overexpression constructs, substrates, and time in culture (Blackmore et al., 2012), overexpression of VP16-KLF7 in cultured DRG neurons did not affect neurite outgrowth.

We next asked whether pre-expressing VP16-KLF7, prior to cell culture and the associated axon removal, would impact subsequent neurite outgrowth. In these experiments VP16-KLF7-2A-mCherry or EBFP-2A-mCherry control was delivered to adult DRG neurons by intrathecal injection of AAV8 one week prior to cell culture. This technique

Neurobiology of Disease, Vol. 99 (March 2017): pg. 24-35. DOI. This article is @ Elsevier and permission has been granted for this version to appear in e-Publications@Marquette. Elsevier does not grant permission for this article to be further copied/distributed or hosted elsewhere without the express permission from Elsevier. 
reliably transduces DRG neurons (Parikh et al., 2011; Vulchanova et al., 2010; Wang et al., 2015) and see (Fig. 4A-F). In parallel, we also asked how any effect of VP16-KLF7 might compare to that of a conditioning lesion, in which injury of peripheral sensory axons triggers transcriptional changes that accelerate subsequent neurite outgrowth (Liu et al., 2011; Smith and Skene, 1997). To do so, additional animals received a crush injury to the sciatic nerve, along with injection of Dextran 3000-Alexafluor 488 to label injured DRG cell bodies in lumbar ganglia. One week after viral injection or crush injury, DRG cells were dissociated and cultured overnight on PDL/laminin substrate, and neurite outgrowth quantified in transfected (mCherry + ) or injured (Alexafluor $488+$ ) neurons. Maximal neurite length was significantly elevated in VP16-KLF7 treated neurons compared to EBFP control (EBFP 339.5 $\mu \mathrm{m} \pm$ 40.1SEM, VP16-KLF8 426.1 $\mu \mathrm{m} \pm$ 45.8SEM, p < 0.01, ANOVA with post-hoc Dunnett's). Notably, however, VP16-KLF7 effect was quite modest compared to that of preconditioning, which produced lengths of $1065.9 \mu \mathrm{m} \pm 70.7 \mathrm{SEM}$, significantly larger than both EBFP and VP16-KLF7 ( $\mathrm{p}<0.01$, ANOVA with post-hoc Dunnett's). Combined, these data indicate that forced expression of VP16-KLF7 modestly increases neurite outgrowth in DRG neurons when expressed prior to axotomy, although it does not recapitulate the full effect of a conditioning lesion.

\subsection{Construction and validation of lenti-chondroitinase}

Besides neuron-intrinsic constraints to axon growth, axon growth in the CNS is also limited by extrinsic cues including CSPGs, and cleavage of GAG side chains from CSPG core proteins by chondroitinase enzyme enhances CNS axon growth in a variety of injury paradigms (reviewed in (Bradbury and Carter, 2011; Kwok et al., 2008)). Moreover, viral transduction with chondroitinase-expressing vectors has been well developed as an effective means to achieve long-term delivery of chondroitinase enzyme to CNS tissue (Bartus et al., 2014; Jin et al., 2011; Muir et al., 2010; Zhao et al., 2011). We therefore designed and synthesized DNA to drive expression of chondroitinase in mammalian cells, and cloned this DNA into a plasmid suitable for subsequent production of lentiviral particles (Fig. 2A; sequence in Supplemental file 1). Similar to previous constructs, the synthesized DNA was based on Proteus vulgaris chondroitinase ABC (accession number $\mathrm{AAB} 43331$ ) and was codon-optimized for mammalian expression (Muir et al., 2010; Zhao et al., 2011). To facilitate secretion, a signal sequence from matrix metalloprotease two (MMP2, Accession NM008610) was included, a strategy conceived and previously validated by (Zhao et al., 2011). In addition, the construct included point mutations that have previously been shown to increase thermostability (Nazari-Robati et al., 2013) and to increase secretion by blocking inappropriate N-glycosylation (Muir et al., 2010; Zhao et al., 2011).

Neurobiology of Disease, Vol. 99 (March 2017): pg. 24-35. DOI. This article is @ Elsevier and permission has been granted for this version to appear in e-Publications@Marquette. Elsevier does not grant permission for this article to be further copied/distributed or hosted elsewhere without the express permission from Elsevier. 
To confirm secretion and enzymatic activity we transfected HEK293 cells with plasmid DNA coding for chondroitinase or mCherry control. Two days later, the culture supernatant was collected and tested for chondroitinase activity by DMMB assay, in which the absorption spectrum shifts in proportion to binding by intact GAG chains. Chondroitinase activity in culture supernatants was compared to standard curves generated using known quantities of chondroitinase enzyme acting on CSPG substrate. As shown in Fig. 1B, chondroitinase activity was not detected in the supernatant of mCherrytransfected 293 cells, but was readily detectable in supernatant from chondroitinasetransfected HEK293 cells, with activity between 7 and $10 \mathrm{U} / \mathrm{ml}$. These values compare favorably with previous estimates of secreted chondroitinase activity from transfected cells (0.2-4 U/ml) (Kanno et al., 2014; Zhao et al., 2011). Overall these data confirm production and secretion of enzymatically active chondroitinase from mammalian cells after transfection with chondroitinase plasmid.

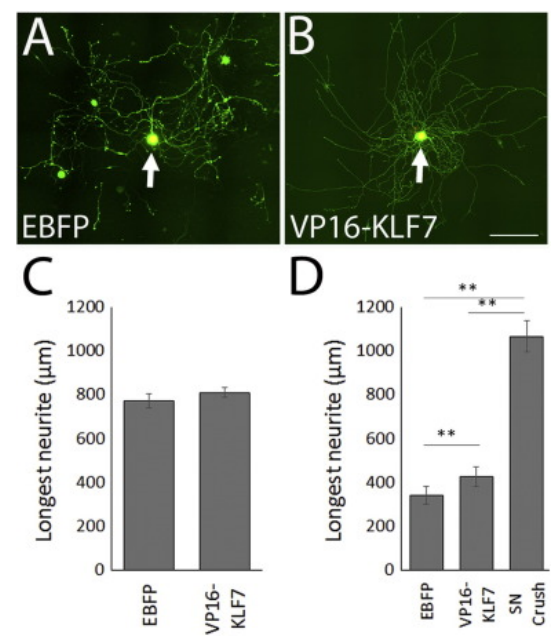

Fig. 1. VP16-KLF7 increases DRG neurite length when expressed prior to axotomy. (A,B) DRG neurons were prepared from adult mice, transfected with EBFP-2A-mCherry control or VP16KLF7-2A-mCherry, and cultured on laminin substrate. After two days, transfected neurons were identified by mCherry expression (arrows) and their longest neurite traced. (C) VP16-KLF7 expression did not significantly

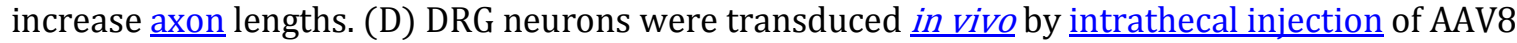
carrying EBFP-2A-mCherry or VP16-2A-mCherry. Separate animals received crushes of the sciatic nerve. One week later, DRG neurons were cultured on laminin substrate for $24 \mathrm{~h}$, and the longest neurite of transduced $(\mathrm{mCherry}+)$ neurons traced. VP16-KLF7 transduced neurons grew significantly longer neurites than EBFP-expressing neurites, but remained significantly shorter than pre-injured DRG neurons. ${ }^{* *} \mathrm{p}<0.01$, paired ANOVA with post-hoc Dunnett's. N $>150$ neurons in three replicate experiments. Scale bar is $100 \mu \mathrm{m}$.

Neurobiology of Disease, Vol. 99 (March 2017): pg. 24-35. DOI. This article is (C) Elsevier and permission has been granted for this version to appear in e-Publications@Marquette. Elsevier does not grant permission for this article to be further copied/distributed or hosted elsewhere without the express permission from Elsevier. 

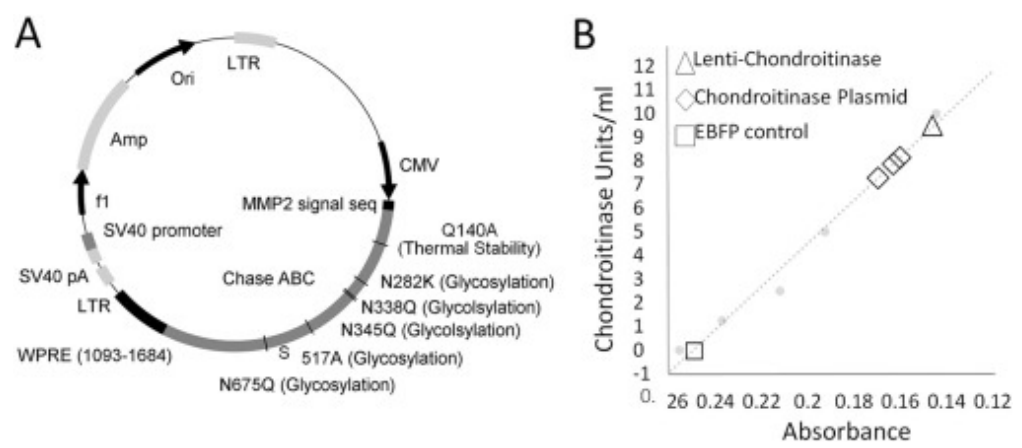

Fig. 2. Lentiviral transduction drives the secretion of functional chondroitinase in mammalian cells. (A) shows the design of plasmid DNA used for the production of Lenti-Chase, indicating mutations to enhance thermal stability and to block aberrant glycosylation. (B) 293T cells were transfected with plasmid encoding EBFP control or chondroitinase, or transduced with Lenti-chase, and the conditioned media tested for chondroitinase activity by colorimetric DMMB assay. Compared to a standard curve of chondroitinase activity (grey circles), media from EBFP-transfected cells showed $<0.1 \mathrm{U} / \mathrm{ml}$ chondroitinase activity media from cells transfected or virally transduced to express chondroitinase showed $>7 \mathrm{U} / \mu \mathrm{l}$.

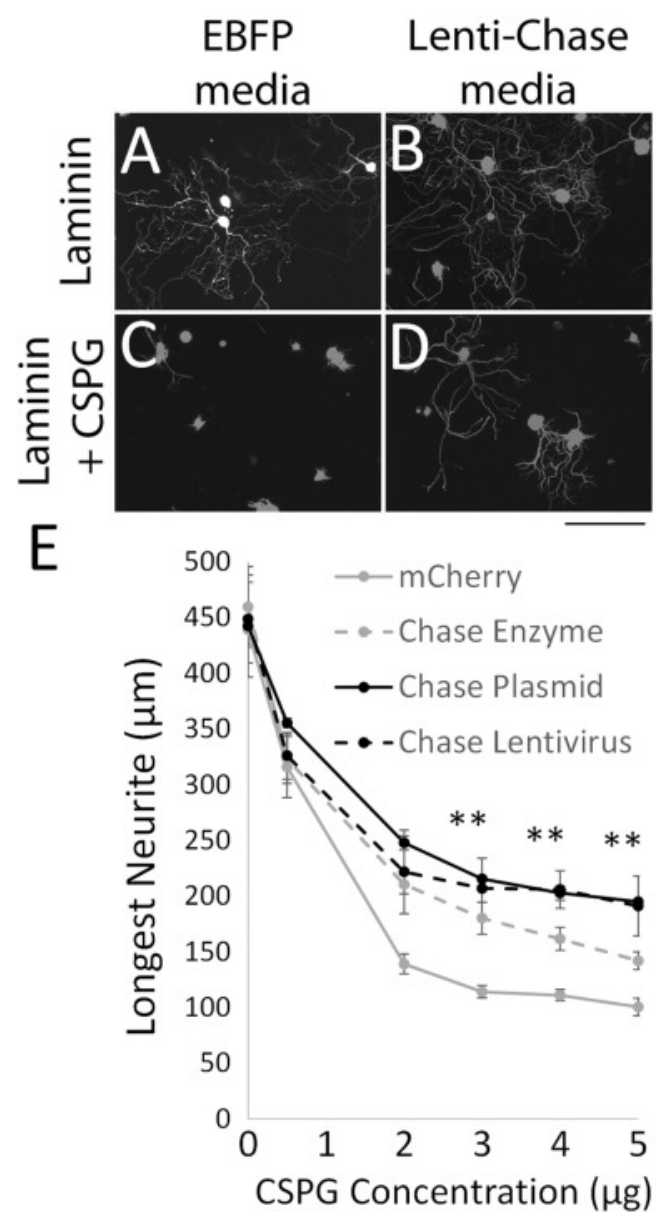

Fig. 3. Chondroitinase secreted by transfected cells reduces inhibition of axon growth by CSPGs. (A-D) DRG neurons were cultured for $24 \mathrm{~h}$ on substrates of laminin alone or laminin mixed with CSPG, and

Neurobiology of Disease, Vol. 99 (March 2017): pg. 24-35. DOI. This article is C Elsevier and permission has been granted for this version to appear in e-Publications@Marquette. Elsevier does not grant permission for this article to be further copied/distributed or hosted elsewhere without the express permission from Elsevier. 
treated with conditioned media from 293T cells transfected with control mCherry or lentichondroitinase. CSPG substrate strongly reduced neurite outgrowth (C), an effect partially blocked by Lenti-Chase media (D). (E) shows 48 h quantification of DRG neurite growth in $25 \mathrm{U} / \mathrm{ml}$ chondroitinase enzyme, or in in media conditioned by 293 cells transfected with mCherry plasmid, chondroitinase plasmid, or Lenti-Chase. In control mCherry-transfected conditions, average neurite lengths were reduced by $>70 \%$ at CSPG concentrations of $2 \mu \mathrm{g}$ or higher $(\mathrm{p}<0.01$, ANOVA with post-hoc Dunnett's). Lenti-Chase media had no effect on neurite length on laminin substrate without CSPGs, but significantly increased length on CSPG substrates at concentrations of $\geq 3 \mu \mathrm{g} / \mathrm{ml}$, indicating active chondroitinase. The longest neurite from $>100$ cells in each of three replicate experiments was measured. ${ }^{* *} \mathrm{p}<0.01$, ANOVA with post-hoc Dunnett's. Scale bar is $100 \mu \mathrm{m}$.
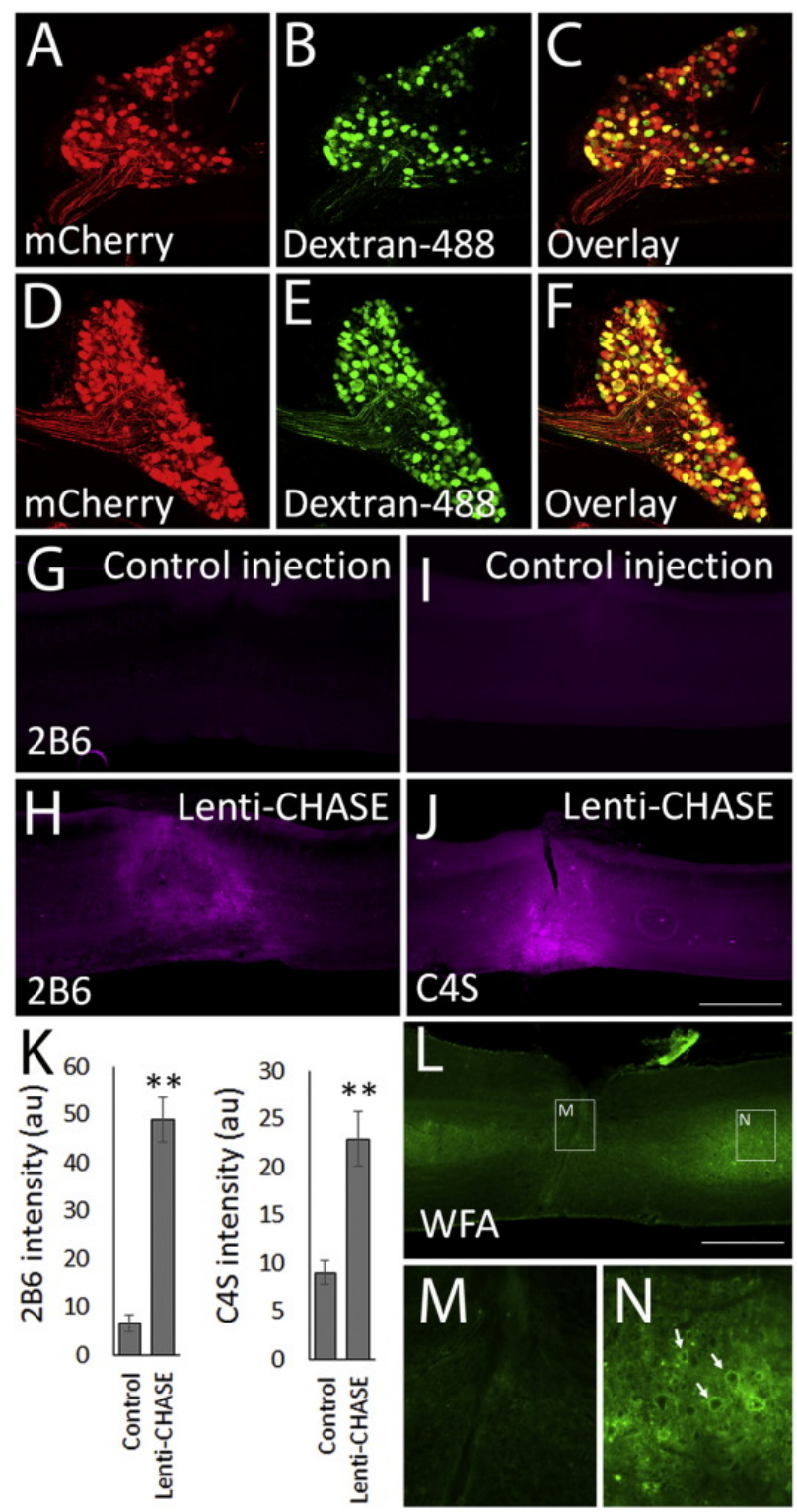

Fig. 4. In vivo verification of sensory neuron transduction and viral expression of chonroitinase. (A-F). AAV8-EBFP-2A-mCherry (A-C) or AAV-VP16KLF7-2A-mCherry (D-E) were delivered by lumbar 
puncture to adult mice. Four weeks later, Dextran-Alexafluor-488 was injected to the sciatic nerve to identify and trace lumbar sensory neurons. After two weeks animals were sacrificed and lumbar DRGs examined. $>87 \%$ of Dextran-488 + DRG neurons were also labeled with viral mCherry in both groups, indicated efficient transduction. $\mathrm{N} \geq 9$ animals for each group. (G-K) Adult mice received cervical dorsal hemisections and injections of either PBS (G, I) or Lenti-Chase particles (H, J). Six weeks later, immunohistochemistry with 2B6 antibodies $(G, H)$ or C4S antibodies (I, J) to visualize CSPG stub epitopes showed readily detectable signal in Lenti-chase treated, but not control animals. Quantification of fluorescence intensity of 2B6 and C4S staining shows significant elevation in Lenti-Chase injected animals, indicating cleavage of CSPG side chains. $\mathrm{N}=15$ control injected animals, 22 Lenti-chase injected animals. Error bars indicate SEM, ${ }^{* *} \mathrm{p}<0.0$, paired $t$-test. (L-N) WFA staining for perineuronal nets shows a strong reduction in the vicinity of Lenti-Chase injection (M) compared to distant tissue (N). Scale bars are $500 \mu \mathrm{m}$.

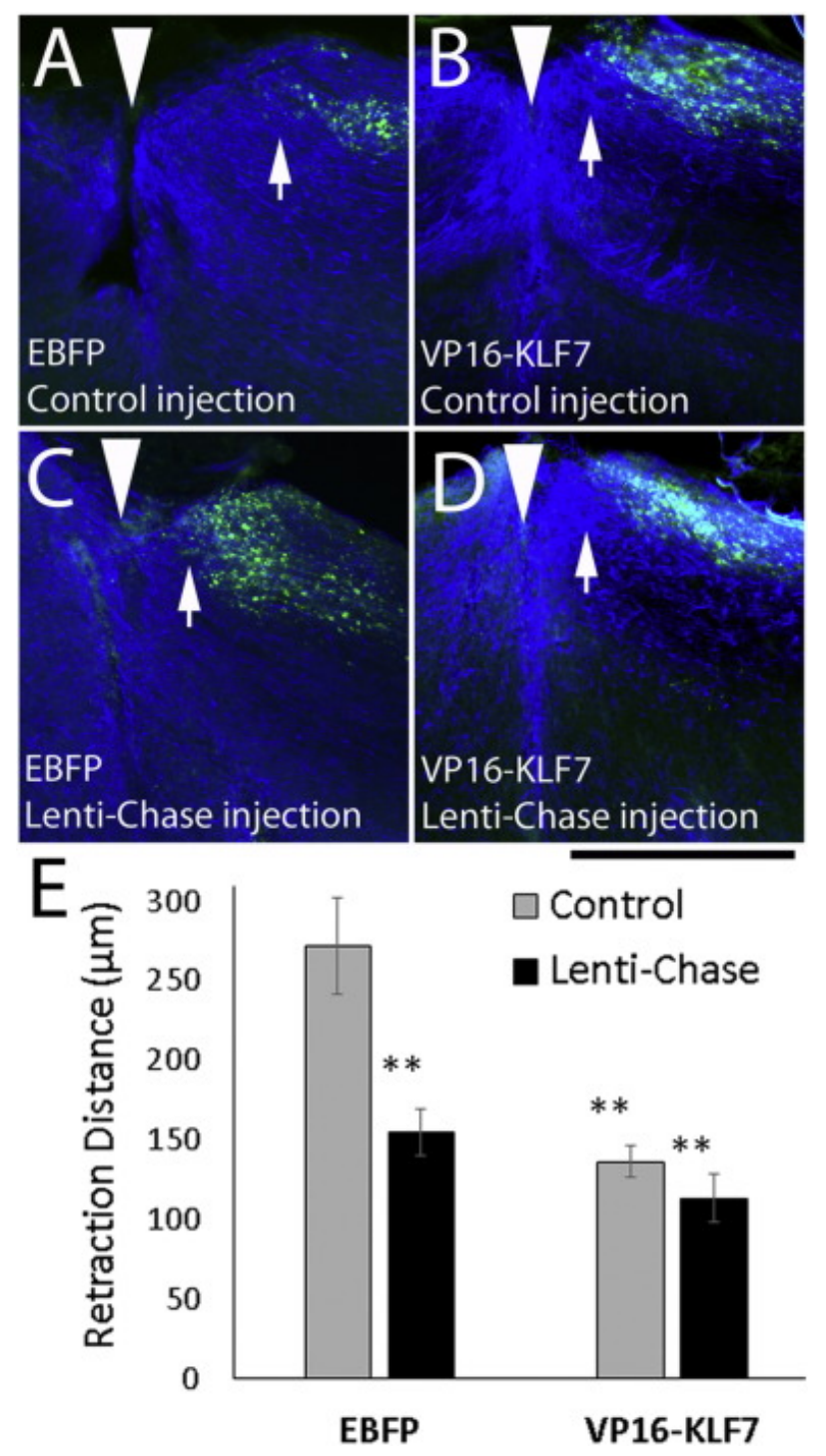

Fig. 5. VP16-KLF7 and lenti-chondroitinase increase the proximity of injured sensory axons to sites of spinal injury but do not promote regeneration beyond the injury. Sensory neurons in adult mice were 
NOT THE PUBLISHED VERSION; this is the author's final, peer-reviewed manuscript. The published version may be accessed by following the link in the citation at the bottom of the page.

transduced by lumbar puncture delivery of AAV-EBFP-2A-mCherry or AAV-VP16-2A-mCherry by lumbar puncture, and received cervical dorsal hemisections accompanied by either control injections or spinal injections of Lenti-Chase. Four weeks later ascending sensory axons were labeled by injection of Dextran-Alexafluor 488 injections to the sciatic nerve, and then sacrificed two weeks later. (A-D) show sagittal sections of spinal cord with GFAP (blue) outlining the site of spinal transection (arrowhead). Ascending Dextran-labeled sensory axons (arrow) are green. Compared to controls (A), individual treatment with VP16-KLF7 (B) and Lenti-Chase (C) resulted in axon growth that approached nearer to the lesion center. Combined VP16KLF7 and Lenti Chase (D) appeared similar to the individual treatments. E. Quantification of the minimum distance between the lesion center and the nearest axon showed a significant reduction from control in both VP16KLF7 and Lenti-Chase treatments, without significant additive effects. $\mathrm{N} \geq 6$ animals per group, ${ }^{* *} \mathrm{p}<0.01$ versus EBFP control, Two way ANOVA with post-hoc Tukey's HSD. Scale bar is $500 \mu \mathrm{m}$.

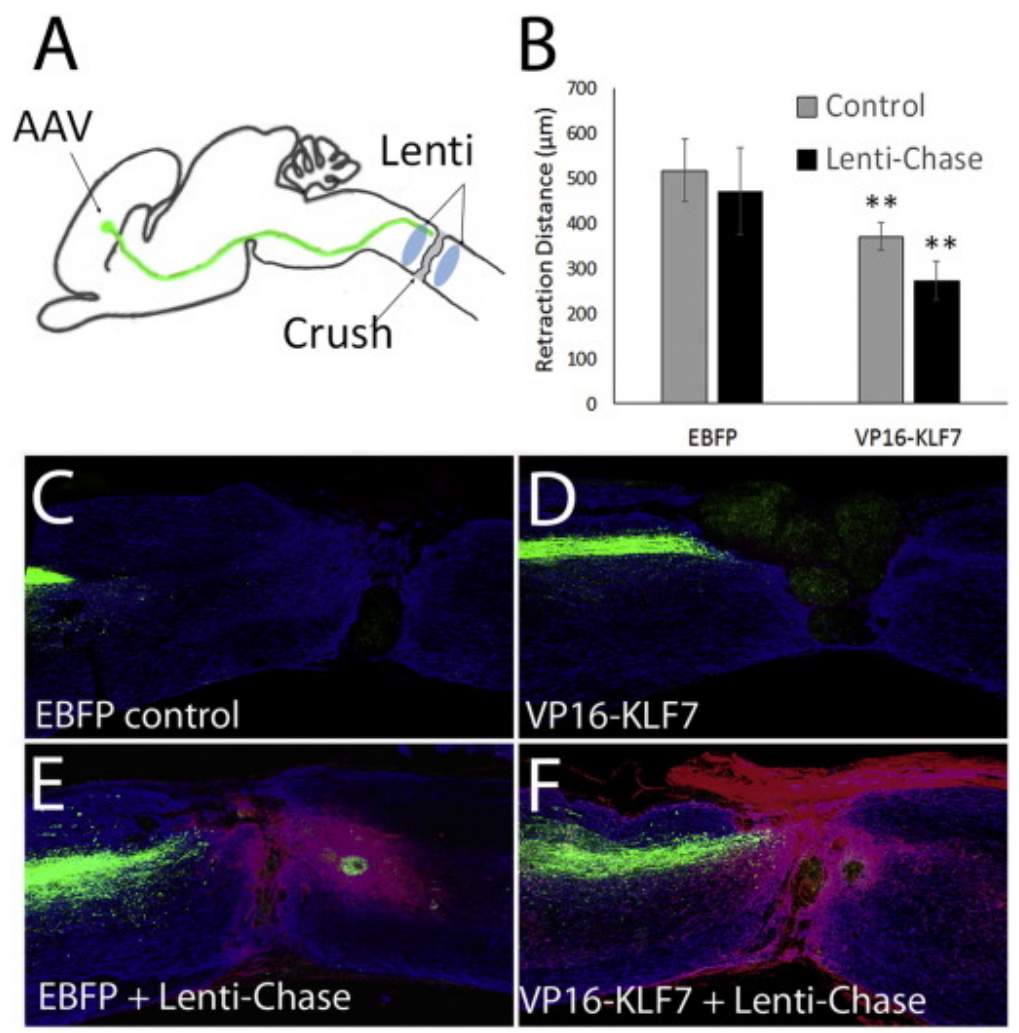

Fig. 6. VP16-KLF7 overexpression in CST neurons enhances proximity of the CST to crush injuries independent of chondroitinase treatment. A. Cortical neurons in adult mice were transduced by injection of AAV-EBFP-2A-mCherry or AAV-VP16-2A-mCherry, along with AAV-EGFP tracer, and received thoracic crush injury accompanied by either control injections or spinal injections of LentiChase. C-F show sagittal sections of spinal cord with GFAP (blue) showing the injury sites, 2B6 (Red) indicating areas of CSPG degradation, and transduced CST axons (Green, EGFP). Compared to EBFP control (C), VP16-KLF7 transduced axons extend closer to the injury site, but do not extend through the injury center in either the absence (D) or presence (F) of lenti-chondroitinase. Quantification of the distance between EGFP + axon tips and the center of the injury shows significant reduction in VP16KLF7 treated animals. $\mathrm{N}=9$ animals per group, ${ }^{* *} \mathrm{p}<0.01$ versus $\mathrm{EBFP}$ control, Two way ANOVA with Tukey's HSD. Scale bar is $500 \mu \mathrm{m}$. 
NOT THE PUBLISHED VERSION; this is the author's final, peer-reviewed manuscript. The published version may be accessed by following the link in the citation at the bottom of the page.

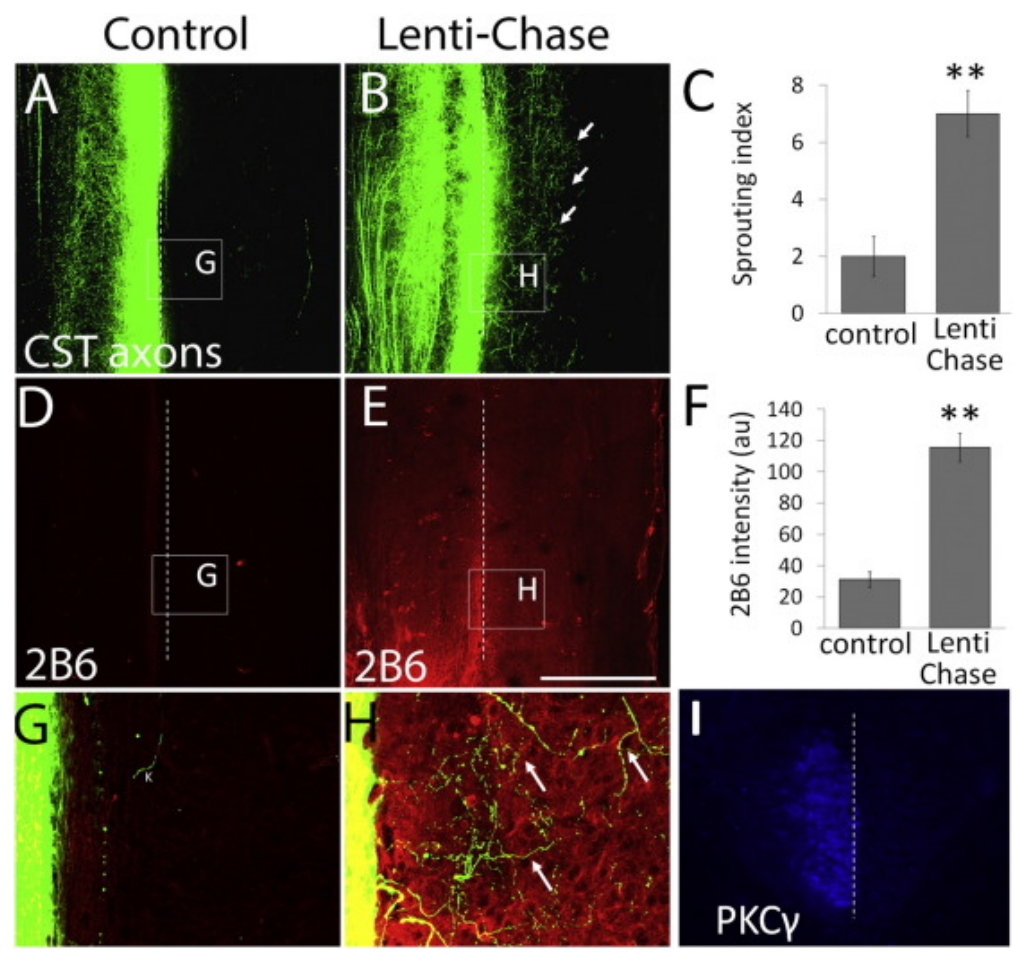

Fig. 7. Lenti-chondroitinase promotes cross-midline sprouting of spared cervical CST axons after unilateral pyramidotomy. Unilateral pyramidotomy was performed to deprive the right spinal cord of CST input, and intact CST axons in the left spinal cord were labeled by cortical injection of AAV8-EGFP. C3/4 spinal cord received injections of PBS control or Lenti-Chase $(A, B)$ Horizontal sections of cervical spinal cord with labeled CST axons (green) and the midline indicated by the dotted line. Cross-midline sprouting is present in lenti-chondroitinase treated tissue (C) 4 weeks post-injury, significantly more CST axons sprout across the midline in Lenti-chase treated animals. (D-F) 2 B6 immunohistochemistry shows significant elevation in Lenti-chase treated animals, confirming CSPG degradation. (G, H) Show detailed views of sprouting CST axons (green) and 2B6 label (red) in control (G) and Lenti-Chase (H) tissue. (I) Transverse sections of the dorsal columns in thoracic spinal cord were stained with PKC gamma to confirm complete pyramidotomy. $\mathrm{N} \geq 4$ animals per group, ${ }^{* *} \mathrm{p}<0.01$ paired $t$-test. Scale bar is $500 \mu \mathrm{m}$.

To further validate the activity of secreted chondroitinase, we next tested conditioned media in assays of CSPG-mediated inhibition of neurite outgrowth. Adult dorsal root ganglia neurons were cultured on substrates of laminin $(10 \mu \mathrm{g} / \mathrm{ml})$ or mixtures of laminin and CSPGs $(0.5,2.0,3.0,4.0$, or $5.0 \mu \mathrm{g} / \mathrm{ml})$, and neurite lengths quantified after two days in culture (Fig. 3A-D). As expected from previous work (Dou and Levine, 1994; ఏin et al., 2011; Niederost et al., 1999; Snow et al., 1996), increasing concentrations of CSPGs significantly reduced the length of the longest neurite from an average of $439.03 \mu \mathrm{m}$ $( \pm 42.62 \mu \mathrm{m}$ SEM) on laminin to $<140 \mu \mathrm{m}$ at CSPG concentration of $2 \mu \mathrm{g}$ or higher ( $\mathrm{p}<0.001$, ANOVA with post-hoc Dunnett's). As a positive control, chondroitinase enzyme (25 U/ml) increased neurite lengths by approximately $50 \%$ on CSPG-containing substrate, without affecting growth on laminin. Similarly, media conditioned by 293T cells transfected

Neurobiology of Disease, Vol. 99 (March 2017): pg. 24-35. DOI. This article is C Elsevier and permission has been granted for this version to appear in e-Publications@Marquette. Elsevier does not grant permission for this article to be further copied/distributed or hosted elsewhere without the express permission from Elsevier. 
with plasmid chondroitinase, but not mCherry, significantly increased neurite lengths by approximately $80 \%$ on CSPG-containing substrates ( $p<0.01$, ANOVA with post-hoc Dunnett's), without affecting neurite lengths on substrates of pure laminin. We next generated lentiviral particles encoding chondroitinase and repeated the experiment, with similar results; compared to control media, lenti-chondroitinase media increased neurite lengths on CSPG substrates between 80 and 90\%, without any effect on pure laminin substrate ( $\mathrm{p}<0.001$, ANOVA with post-hoc Dunnett's) (Fig. 3E). Combined, these data indicate that similar to previous findings (Џin et al., 2011; Muir et al., 2010), viral transduction with lenti-chondroitinase drives secretion of active chondroitinase enzyme that acts to partially relieve CSPG-mediated inhibition of neurite outgrowth.

\subsection{Effects of VP16-KLF7 overexpression and lenti-chondroitinase on central axon regeneration by sensory neurons}

We next performed in vivo experiments to test the ability of VP16-KLF7 overexpression and lentiviral-produced chondroitinase to increase axon regeneration by ascending sensory fibers after dorsal column injury. AAV8-VP16-KLF7 or control AAV8EBFP were delivered to adult mice by lumbar puncture, a method that we and others have shown to specifically and effectively transduce sensory neurons (Parikh et al., 2011; Vulchanova et al., 2010; Wang et al., 2015). Both constructs expressed mCherry reporter via a $2 \mathrm{~A}$ peptide sequence, as previously (Blackmore et al., 2012; Wang et al., 2015). One week later, mice received a dorsal transection of cervical spinal cord (C5) and intraspinal injection of either Lenti-Chase or vehicle control $1 \mathrm{~mm}$ rostral and caudal to the site of injury. To trace ascending axons, all animals received injections of Dextran 3000-Alexafluor 488 into sciatic nerves, which we and others have shown to act as an effective transganglionic tracer (Parikh et al., 2011; Wang et al., 2015). We employed this transganglionic labeling strategy, as opposed to relying on viral mCherry expression in DRG axons, because the viral mCherry signal is not consistently bright enough to function as an effective axonal tracer. In addition, the potential for the virus itself to spread rostral to the injury renders it unable to distinguish injured axons that originate caudal to the injury from spared axons generated by upper cervical DRGs.

Animals were sacrificed six weeks post-injury and examined to confirm viral transduction. Inspection of lumbar dorsal ganglia from nine EBFP-2A-mCherry and ten VP16KLF7-2A-mCherry animals showed that $87.8 \pm 5.6 \%$ and $88.6 \pm 5.2 \%$ of dextranlabeled DRG cells also expressed mCherry (Fig. 4A-F). These data confirm efficient viral transduction of lumbar DRG neurons, and indicate that the majority of dextran-positive DRG axons in the spinal cord (see below) arose from virally transduced cell bodies. To

Neurobiology of Disease, Vol. 99 (March 2017): pg. 24-35. DOI. This article is @ Elsevier and permission has been granted for this version to appear in e-Publications@Marquette. Elsevier does not grant permission for this article to be further copied/distributed or hosted elsewhere without the express permission from Elsevier. 
assess viral-mediated degradation of CSPGs, sagittal sections of spinal cord spanning the injury site were prepared and immunohistochemistry performed with 2B6 and C4S antibodies, which recognize carbohydrate stub epitopes generated by chondroitinase's cleavage of GAG chains (Bartus et al., 2014; Bukhari et al., 2011; Cafferty et al., 2008; Cheng et al., 2015). 2B6 and C4S reactivity were both readily detectable in animals injected with Lenti-Chase, but not vehicle control (Fig. 4G-J). Quantification of 2B6 and C4S fluorescence within the injury site showed an approximately 8-fold and 3-fold increase, respectively, in

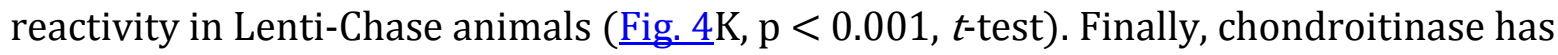
been shown previously to degrade perineuronal nets, which can be visualized with the lectin Wisteria floribunda (WFA) (Howell et al., 2015; Soleman et al., 2012: Starkey et al., 2012; Wang et al., 2011). Indeed, WFA labeling of perineuronal nets was abolished in the vicinity of injected Lenti-Chase (Fig. 4L-N). Thus 2B6, C4S, and WFA staining consistently indicate effective viral expression of chondroitinase and degradation of CSPGs.

To assess axon regeneration, Dextran-labeled ascending axons were examined in sagittal sections of cervical spinal cord. GFAP a marker for reactive gliosis, was used to locate the site of transection injury (Fig. 5A-D). No axons were observed to regenerate to locations rostral to the injury, regardless of VP16-KLF7 or chondroitinase transfection. Differences were noted, however, in the proximity of injured axons to the injury center. In control conditions, axons showed a net retraction of $272.3 \pm 30.2 \mu \mathrm{m}$ SEM from the injury site. DRG axons in chondroitinase-expressing animals were located $154.8 \pm 38.2 \mu \mathrm{m}$ from the injury center, significantly closer than control ( $p<0.01,2$ Way ANOVA Tukey's HSD). VP16-KLF7 transduction similarly reduced net retraction to $136.7 \pm 27.2 \mu \mathrm{m}$ SEM ( $p<0.01$ versus control, ANOVA with Tukey's HSD). Combined treatment with both chondroitinase and VP16-KLF7 showed a trend toward further reduction in net retraction $(113.6 \pm 14.9 \mu \mathrm{m} S E M)$, but did not differ significantly from either treatment alone. Combined, these data show that expression of VP16-KLF7 and the presence of chondroitinase did not promote long-distance DRG regeneration after spinal injury, but did act to reduce injury-induced axonal retraction, or alternatively facilitated partial regrowth of axons toward the lesion center.

\subsection{Effects of VP16-KLF7 overexpression and lenti-chondroitinase on CST regeneration after complete crush injury}

We have shown previously that forced expression of VP16-KLF7 in CST neurons promotes sprouting after unilateral pyramidotomy, and axon regeneration after cervical injury (Blackmore et al., 2012). Importantly, regeneration was stimulated in a dorsal hemitransection injury, and VP16-KLF7 treated axons regenerated by circumventing the injury

Neurobiology of Disease, Vol. 99 (March 2017): pg. 24-35. DOI. This article is @ Elsevier and permission has been granted for this version to appear in e-Publications@Marquette. Elsevier does not grant permission for this article to be further copied/distributed or hosted elsewhere without the express permission from Elsevier. 
via spared ventral tissue, and did not traverse the injury site. To determine whether VP16KLF7 expression can stimulate CST axon regeneration in a more complete injury, that is, in the absence of spared tissue, we used a crush injury model. Adult mice received cortical injections of AAV8-VP16-KLF7-2A-mCherry or AAV8-EBFP-2A-mCherry control along with AAV8-EGFP at a 1:2 ratio to act as a tracer of transduced CST axons in the spinal cord. This co-injection strategy has been used previously by our group and others in spinal injury experiments, and results in co-expression of the test gene in $>90 \%$ of EGFP + cells (Blackmore et al., 2012; Wang et al., 2015). One week after viral injection animals received a crush of T8 spinal cord using Dumont forceps. At the time of injury animals also received Lenti-Chase, or carrier control injections, rostral and caudal to the crush site. Animals were sacrificed eight weeks post-injury and sagittal sections of spinal cord were prepared. Immunohistochemistry for GFAP defined the edges of the crush injury. To quantify relative lesion sizes, the area within the GFAP-positive rim was measured in the sagittal plane. On average, the lesion area was approximately $45 \%$ smaller in animals that received LentiChase ( $0.44 \mathrm{~mm}^{2}$ in control, $0.24 \mathrm{~mm}^{2}$ in control, $\mathrm{p}=0.013$, paired $t$-test). This reduction in lesion size is consistent with a recent report that chondroitinase treatment reduces lesion volume after spinal contusions, likely by modulating macrophage responses (Bartus et al., 2014; Cheng et al., 2015). Immunohistochemistry for 2B6, the carbohydrate stub produced by chondroitinase-mediate cleavage of GAG chains from CSPGs, confirmed degradation in lenti-chondroitinase treated animals (ig. 6).

EGFP-positive axonal profiles were examined to determine the growth response of injured CST axons. As expected, in control animals (cortical EBFP, spinal PBS), CST axons failed to traverse the injury site and showed evidence of retraction from the injury boundary, with the shortest distance between CST axons and the injury edge averaging $517.8 \mu \mathrm{m} \pm 69.8 \mathrm{SEM}$. Animals treated with cortical VP16-KLF7 showed no evidence for CST extension into the injury site, but did show increased proximity of the CST axon tips to the rostral edge of the injury $(371 \mu \mathrm{m} \pm 30.0 \mathrm{SEM}, \mathrm{p}<0.05 \mathrm{VS}$. control, 2-way ANOVA, Tukey's HSD). Injection of chondroitinase virus resulted in an average axon-injury gap of $471.5 \mu \mathrm{m} \pm 97.5 \mathrm{SEM}$, not significantly different from control. Finally, animals that received both VP16-KLF7 and chondroitinase displayed axon-injury distances that averaged $273.0 \mu \mathrm{m} \pm 42.8 \mathrm{SEM}$, significantly different $(\mathrm{p}<0.01)$ from control, but not significantly different from VP16-KLF7 alone ( $p>0.05$, 2-Way ANOVA with Tukey's HSD). These data indicate that VP16-KLF7 treatment either reduced axonal retraction from the injury, or alternatively, may have promoted minimal and abortive regrowth of axons toward the injury site after initial retraction. Thus neither VP16-KLF7, nor Lenti-chondroitinase, applied singly or in combination, enabled regeneration into the injury site.

Neurobiology of Disease, Vol. 99 (March 2017): pg. 24-35. DOI. This article is @ Elsevier and permission has been granted for this version to appear in e-Publications@Marquette. Elsevier does not grant permission for this article to be further copied/distributed or hosted elsewhere without the express permission from Elsevier. 
Finally, we considered the possibility that the inability of lenti-chondroitinase to stimulate CST growth into complete injuries could reflect technical limitations of the viral reagent, that is, degradation of CSPGs that was below the threshold needed to evoke a response from CST axons. We therefore tested lenti-chondroitinase reagent for the ability to stimulate CST sprouting in cervical spinal cord after unilateral pyramidotomy, a model in which chondroitinase has shown consistent effects on axon growth (Lee et al., 2014; Starkey et al., 2012). The right spinal cord of adult mice was deprived of CST input by lesion in the medullary pyramids, and the left (intact) CST was labeled by cortical injection of AAV8-EGFP. PBS control or lenti-chondroitinase were injected bilaterally to C3 and C4 spinal cord. Four weeks later, animals were sacrificed and horizontal sections of cervical spinal cord were prepared. As expected, 2B6 staining was strongly increased by lentichondroitinase treatment, indicating CSPG degradation (Fig. 7D-F; $p<0.01$, paired $t$-test). $\mathrm{PKC} \gamma$ immunohistochemistry, a well-established label of CST axons, confirmed complete

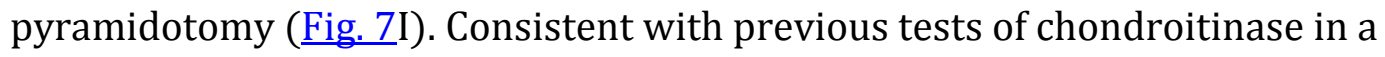
pyramidotomy model (Lee et al., 2014; Starkey et al., 2012), Lenti-chase treatment significantly enhanced CST sprouting, with a four-fold increase in the number of EGFP + profiles at $250 \mu \mathrm{m}$ to the right of the midline ( $\mathrm{p}<0.01$, paired $t$-test, Fig. $7 \mathrm{~A}-\mathrm{C}$ ). These data confirm that degradation of CSPGs by lenti-chondroitinase is sufficient to evoke a robust sprouting response from CST axons, and argue against technical limitations of the lentichondroitinase as the explanation for the lack of regeneration in the thoracic crush paradigm. Instead, the lack of robust chondroitinase-evoked regeneration in the thoracic crush injury likely highlights the need for additional or alternative strategies to promote CST regeneration in conditions of complete spinal injury.

\section{Discussion}

Here we examined the combined effects of forced expression of the proregenerative transcription factor KLF7 and expression of chondroitinase from spinal tissue on axon regeneration. In vitro assays of DRG outgrowth confirmed the ability of virally produced chondroitinase to partially relieve inhibition by CSPGs substrate and a modest effect of VP16-KLF7 expression when pre-expressed in cultured DRG neurons. After transection of centrally projecting sensory axons in vivo, both VP16-KLF7 overexpression and virally expressed chondroitinase narrowed the distance between injured axons and the injury center, but neither treatment, singly or in combination, resulted in axon growth beyond the site of injury. Similarly, when CST axons were challenged with a complete crush injury, VP16-KLF7 expression decreased net retraction from the injury, but did not enable axons to penetrate the lesion scar or beyond. These experiments implicate KLF7 activity

Neurobiology of Disease, Vol. 99 (March 2017): pg. 24-35. DOI. This article is @ Elsevier and permission has been granted for this version to appear in e-Publications@Marquette. Elsevier does not grant permission for this article to be further copied/distributed or hosted elsewhere without the express permission from Elsevier. 
and CSPG inhibition in determining the net retraction of injured axons from sites of axotomy in both sensory and motor axons in the spinal cord, but also illustrate the need to engage additional pathways to promote full-fledged regeneration.

\subsection{Effects of lenti-chondroitinase on ascending and descending axon regeneration}

Consistent with previous work, we found here that lentiviral transduction drove the secretion of active chondroitinase enzyme from transduced cells, as confirmed by DBBD enzyme assay, neurite outgrowth assays in vitro, and the emergence of GAG "stub" antibody reactivity after injections in vivo. Lenti-Chase delivered to sites of spinal injury resulted in a reduction in the net retraction of injured DRG axons from sites of spinal transection. The distance between the injury and injured axon tips is affected both by the initial retraction of axons, and the distance re-extended in the course of abortive regenerative attempts. It was shown previously that DRG axon retraction after spinal injury is initiated within minutes and maximal within $24 \mathrm{~h}$ (Kerschensteiner et al., 2005). Thus, because this timeframe is considerably shorter than that required for lentiviral transduction and full protein secretion, it is highly unlikely that Lenti-Chase affects the initial retraction of DRG axons. It is therefore most probable that the increased proximity of DRG axons to the lesion is caused by a small increase in the distance of subsequent regrowth.

Although chondroitinase caused incremental regrowth of ascending sensory axons toward the injury site, it did not enable robust regeneration beyond the lesion. Similarly, (Lee et al., 2010a), found that sustained release of thermostabilized chondroitinase resulted in increased numbers of ascending sensory axons at the caudal edge of a transection injury, but not extension rostral to the injury. Using a dorsal transection injury very similar to the one used here and intraparenchymal injections of chondroitinase, (Shields et al., 2008) showed a significant increase in the number of ascending axons that approached the injury core, while chondroitinase-evoked regeneration beyond the caudal boundary lesion of the injury averaged 700um. Although this response is slightly larger than in the current report, our findings that chondroitinase reduces the net retraction of DRG axons from sites of dorsal column injury, without a strong effect on axon regrowth through or around the injury site, are broadly consistent.

Similarly, we found that chondroitinase expression did not strongly enhance CST regeneration after a crush injury to the thoracic spinal cord. Previous reports regarding the effects of chondroitinase treatment on CST growth have been variable, and appear to be

Neurobiology of Disease, Vol. 99 (March 2017): pg. 24-35. DOI. This article is @ Elsevier and permission has been granted for this version to appear in e-Publications@Marquette. Elsevier does not grant permission for this article to be further copied/distributed or hosted elsewhere without the express permission from Elsevier. 
influenced by differences in injury models. A number of studies report that application of chondroitinase to models of partialspinal cord injury, which spare lateral and/or ventral CST tracts, leads to increases in CST density at locations rostral, adjacent, and caudal to sites of spinal injury (Bradbury et al., 2002; Barritt et al., 2006; Iseda et al., 2008; GarciaAlias et al., 2009; Zhao et al., 2011; Starkey et al., 2012). Although this response has occasionally been described as CST regeneration, it can be difficult in partial injury models to distinguish regeneration from sprouting (Tuszynski and Steward, 2012). Indeed, it is clear from numerous studies that CST axons respond to chondroitinase-mediated degradation of GAGs with increased sprouting of collateral arborization into spinal tissue (Alluin et al., 2014; Barritt et al., 2006; Garcia-Alias et al., 2009; Starkey et al., 2012; Zhao et al., 2011). Similarly, our results in the pyramidotomy injury model show clearly that lentichondroitinase promotes collateral sprouting of CST axons into denervated tissue (Fig. 7), and it also appeared that in the crush model CST axons treated with Lenti-chase displayed increased collateral sprouting rostral to the injury (Compare Fig. 6E,F to C,D). When considering CST regeneration, however, the effects of chondroitinase have been less clear. Indeed, similar to our current results, a number of studies indicate that chondroitinase does not stimulate CST growth beyond complete spinal injuries, including complete transections spanned by transplanted tissue bridges (Fouad et al., 2005; Iseda et al., 2008; Alluin et al., 2014; Kanno et al., 2014). These findings, and the present results, are consistent with the notion that even in the presence of chondroitinase, severe spinal injuries present significant barriers to CST axon extension.

Indeed, there is some question regarding the degree to which removal of GAG chains is sufficient to abolish growth inhibition. In support of the notion that GAG chains confer most of the growth-inhibitory properties, early reports indicated that chondroitinase treatment completely abolished the preference of DRG axons for laminin compared to mixed laminin/CSPG substrates in a stripe assay (Snow et al., 1990), and strongly improved the ability of cerebellar granular neurites to traverse laminin/brevican borders (Yamada et al., 1997). On the other hand, in other border crossing assays involving laminin and laminin mixed with brevican and versican, chondroitinase only partially increased crossing (Niederost et al., 1999). Similarly, in stripe assays of laminin and versican/laminin mixtures, strong preference for laminin stripes persisted after chondroitinase treatment (Schmalfeldt et al., 2000). In a "spot assay" of CSPG inhibition, in which DRG axons are confronted with a gradient of the CSPG aggrecan, chondroitinase treatment produced a significant but quite modest increase in the percent of axons that successfully traversed the

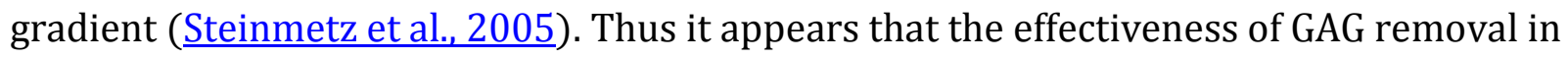
relieving CSPG growth inhibition may vary according to the particular type of CSPG, neurons, and culture system (e.g. homogenous, sharp borders, or gradients of CSPG). Thus,

Neurobiology of Disease, Vol. 99 (March 2017): pg. 24-35. DOI. This article is @ Elsevier and permission has been granted for this version to appear in e-Publications@Marquette. Elsevier does not grant permission for this article to be further copied/distributed or hosted elsewhere without the express permission from Elsevier. 
in the current experiments, one factor contributing to the lack of robust regeneration in the present experiments may be residual inhibition associated with CSPG core proteins.

Another important factor may the amount of chondroitinase delivered. The viral chondroitinase employed in these experiments incorporated design elements previously demonstrated to improve secretion and stability, and enzymatic activity was confirmed in colorimetric and axon outgrowth assays. Activity was further confirmed by immunohistochemistry for chondroitinase-generated carbohydrate "stubs" in vivo. On the other hand, it is notable that inspection of the 2B6 immunoreactivity in these current experiments shows reactivity largely confined to tissue within $1 \mathrm{~mm}$ of the injury, whereas a previous report using lenti-chondroitinase showed intense reactivity extending for many millimeters (Bartus et al., 2014). This could indicate that the previous study achieved more effective viral transduction, higher levels of enzyme secretion, or elevated enzymatic activity. The positive growth response evoked by lenti-chondroitinase in the pyramidotomy model indicates effective production of chondroitinase. Nevertheless, an important caveat to these results is that despite extensive in vitro and in vivo demonstration of enzymatic efficacy, we cannot rule out the possibility that more robust axon growth could result from greater degradation.

\subsection{KLF7 in axon regeneration}

It appears that the effects of forced KLF7 activity on axon regeneration vary according to the cell type and the injury. Previous results with the same VP16-KLF7 treatment showed robust sprouting by spared CST axons after unilateral pyramidotomy, and regeneration by injured CST axons responding to partialspinal injury (Blackmore et al., 2012). In contrast, in the present work VP16-KLF7 did not enable CST axons to extend into or beyond a complete lesion. This is not wholly unexpected, because in the prior partial injury model, VP16-KLF7 stimulated axons were noted to extend only through spared tissue, and not through the lesion site. A likely explanation is that CST neurons expressing VP16-KLF7 display increased basal growth ability, but remain sensitive to extrinsic inhibitory cues at the lesion, which cannot be circumvented in the situation of complete injury.

Perhaps more unexpected is that even when comparing equivalent partial injury models dorsal cervical hemisection, the stimulatory effects of VP16-KLF7 on axon regeneration appear much smaller in DRG neurons than those previously reported in CST neurons. In the present report VP16-KLF7 reduced the net retraction of DRG axons from the injury site, but unlike the CST, did not increase sprouting or stimulate growth that

Neurobiology of Disease, Vol. 99 (March 2017): pg. 24-35. DOI. This article is @ Elsevier and permission has been granted for this version to appear in e-Publications@Marquette. Elsevier does not grant permission for this article to be further copied/distributed or hosted elsewhere without the express permission from Elsevier. 
circumvented the lesion. Consistent with this, the effect of VP16-KLF7 overexpression in cultured DRG neurons were modest compared to previously results in cortical neurons, and appeared only when VP16-KLF7 was expressed prior to culture. Importantly, key experimental conditions (e.g. substrate, time in culture) were held constant between the two cell types, lessening the chance that the different growth phenotypes can be explained by technical variables. Overall these data likely illustrate an intriguing difference in the transcriptional control of axon regeneration in DRG and cortical neurons, such that KLF7 activity produces larger changes in cortical neurons than DRG neurons. Indeed, although in CNS neurons KLF7 expression has been shown to be correlated with (Laub et al., 2001; Veldman et al., 2007), required for (Veldman et al., 2007) and sufficient to improve regenerative success (Blackmore et al., 2012; Moore et al., 2009) in various CNS neurons, a recent comprehensive analysis of transcriptional regulation of DRG regeneration in the periphery did not identify a role for KLF7, although other family members (KLF4 and -5) were implicated (Chandran et al., 2016). Thus, as ongoing efforts are devoted to defining and therapeutically manipulating transcriptional networks that control axon growth, these data highlight the need to clarify how these networks may differ across cell type.

Overall, the current experiments have explored combined VP16-KLF7 and chondroitinase as a novel combinatorial strategy to promote CNS axon growth, motivated by clear effects reported previously for each individual treatment. Although both VP16KLF7 and chondroitinase have proven effective in promoting axon growth by CST neurons into spared tissue, we found that neither intervention, applied singly or in conjunction, enabled CST or DRG axons to traverse sites of spinal injury, although they did significantly decrease the net retraction of axons. Overall the effect of VP16-KLF7 expression on DRG neurons appeared modest compared to those in cortical neurons. Thus, although clearly additional interventions will be needed to stimulate more substantial growth, these data indicate that particularly in the case of injured CST axons, VP16-KLF7 and/or chondroitinase, by virtue of their ability to increase proximity of axons to injury sites, may play in a role in future combinatorial efforts to promote regeneration.

Supplementary data to this article can be found online at http://dx.doi.org/10.1016/j.nbd.2016.12.010.

\section{Acknowledgments}

We wish to thank Dr. Jenn Evans for input and statistical advice. This work was supported by grants

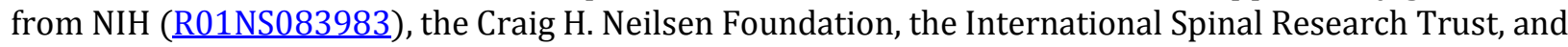
the Bryon Riesch Paralysis Foundation.

Neurobiology of Disease, Vol. 99 (March 2017): pg. 24-35. DOI. This article is (C) Elsevier and permission has been granted for this version to appear in e-Publications@Marquette. Elsevier does not grant permission for this article to be further copied/distributed or hosted elsewhere without the express permission from Elsevier. 
NOT THE PUBLISHED VERSION; this is the author's final, peer-reviewed manuscript. The published version may be accessed by following the link in the citation at the bottom of the page.

\section{References}

Alluin et al., 2014. O. Alluin, H. Delivet-Mongrain, M.K. Gauthier, M.G. Fehlings, S. Rossignol, S. KarimiAbdolrezaee Examination of the combined effects of chondroitinase $\mathrm{ABC}$, growth factors and locomotor training following compressive spinal cord injury on neuroanatomical plasticity and kinematics. PLoS One, 9 (2014), Article e111072

Asher et al., 2002. R.A. Asher, D.A. Morgenstern, M.C. Shearer, K.H. Adcock, P. Pesheva, J.W. Fawcett Versican is upregulated in CNS injury and is a product of oligodendrocyte lineage cells $J$. Neurosci., 22 (2002), pp. 2225-2236

Bandtlow and Zimmermann, 2000 C.E. Bandtlow, D.R. Zimmermann Proteoglycans in the developing brain: new conceptual insights for old proteins Physiol. Rev., 80 (2000), pp. 1267-1290

Barritt et al., 2006. A.W. Barritt, M. Davies, F. Marchand, R. Hartley, J. Grist, P. Yip, S.B. McMahon, E.J. Bradbury Chondroitinase $\mathrm{ABC}$ promotes sprouting of intact and injured spinal systems after spinal cord injury J. Neurosci., 26 (2006), pp. 10856-10867

Bartus et al., 2012 K. Bartus, N.D. James, K.D. Bosch, E.J. Bradbury Chondroitin sulphate proteoglycans: key modulators of spinal cord and brain plasticity Exp. Neurol., 235 (2012), pp. 5-17

Bartus et al., 2014 K. Bartus, N.D. James, A. Didangelos, K.D. Bosch, J. Verhaagen, R.J. Yanez-Munoz, J.H. Rogers, B.L. Schneider, E.M. Muir, E.J. Bradbury Large-scale chondroitin sulfate proteoglycan digestion with chondroitinase gene therapy leads to reduced pathology and modulates macrophage phenotype following spinal cord contusion injury J. Neurosci., 34 (2014), pp. 4822 4836

Ben-Yaakov et al., 2012 K. Ben-Yaakov, S.Y. Dagan, Y. Segal-Ruder, O. Shalem, D. Vuppalanchi, D.E. Willis, D. Yudin, I. Rishal, F. Rother, M. Bader, A. Blesch, Y. Pilpel, J.L. Twiss, M. Fainzilber Axonal transcription factors signal retrogradely in lesioned peripheral nerve $E M B O$ J., 31 (2012), pp. $1350-1363$

Blackmore, 2012 M.G. Blackmore Molecular control of axon growth: insights from comparative gene profiling and high-throughput screening Int. Rev. Neurobiol., 105 (2012), pp. 39-70

Blackmore et al., 2010 M.G. Blackmore, D.L. Moore, R.P. Smith, J.L. Goldberg, J.L. Bixby, V.P. Lemmon High content screening of cortical neurons identifies novel regulators of axon growth $\mathrm{Mol}$. Cell. Neurosci., 44 (2010), pp. 43-54

Blackmore et al., 2012 M.G. Blackmore, Z. Wang, J.K. Lerch, D. Motti, Y.P. Zhang, C.B. Shields, J.K. Lee, J.L. Goldberg, V.P. Lemmon, J.L. Bixby Kruppel-like factor 7 engineered for transcriptional activation promotes axon regeneration in the adult corticospinal tract Proc. Natl. Acad. Sci. U. S. A., 109 (2012), pp. 7517-7522

Bradbury and Carter, 2011 E.J. Bradbury, L.M. Carter Manipulating the glial scar: chondroitinase ABC as a therapy for spinal cord injury Brain Res. Bull., 84 (2011), pp. 306-316

Bradbury et al., 2002 E.J. Bradbury, L.D. Moon, R.J. Popat, V.R. King, G.S. Bennett, P.N. Patel, J.W. Fawcett, S.B. McMahon Chondroitinase $\mathrm{ABC}$ promotes functional recovery after spinal cord injury Nature, 416 (2002), pp. 636-640

Broude et al., 1997 E. Broude, M. McAtee, M.S. Kelley, B.S. Bregman c-Jun expression in adult rat dorsal root ganglion neurons: differential response after central or peripheral axotomy Exp. Neurol., 148 (1997), pp. 367-377

Neurobiology of Disease, Vol. 99 (March 2017): pg. 24-35. DOI. This article is @ Elsevier and permission has been granted for this version to appear in e-Publications@Marquette. Elsevier does not grant permission for this article to be further copied/distributed or hosted elsewhere without the express permission from Elsevier. 
NOT THE PUBLISHED VERSION; this is the author's final, peer-reviewed manuscript. The published version may be accessed by following the link in the citation at the bottom of the page.

Bukhari et al., 2011 N. Bukhari, L. Torres, J.K. Robinson, S.E. Tsirka Axonal regrowth after spinal cord injury via chondroitinase and the tissue plasminogen activator (tPA)/plasmin system J. Neurosci., 31 (2011), pp. 14931-14943

Cafferty et al., 2008 W.B. Cafferty, E.J. Bradbury, M. Lidierth, M. Jones, P.J. Duffy, S. Pezet, S.B. McMahon Chondroitinase ABC-mediated plasticity of spinal sensory function J. Neurosci., 28 (2008), pp. 11998-12009

Chaisuksunt et al., 2000 V. Chaisuksunt, Y. Zhang, P.N. Anderson, G. Campbell, E. Vaudano, M. Schachner, A.R. Lieberman Axonal regeneration from CNS neurons in the cerebellum and brainstem of adult rats: correlation with the patterns of expression and distribution of messenger RNAs for L1, CHL1, c-jun and growth-associated protein-43 Neuroscience, 100 (2000), pp. 87-108

Chandran et al., 2016 V. Chandran, G. Coppola, H. Nawabi, T. Omura, R. Versano, E.A. Huebner, A. Zhang, M. Costigan, A. Yekkirala, L. Barrett, A. Blesch, I. Michaelevski, J. Davis-Turak, F. Gao, P. Langfelder, S. Horvath, Z. He, L. Benowitz, M. Fainzilber, M. Tuszynski, C.J. Woolf, D.H. Geschwind A systems-level analysis of the peripheral nerve intrinsic axonal growth program Neuron, 89 (2016), pp. 956-970

Cheng et al., 2015 C.H. Cheng, C.T. Lin, M.J. Lee, M.J. Tsai, W.H. Huang, M.C. Huang, Y.L. Lin, C.J. Chen, W.C. Huang, H. Cheng Local delivery of high-dose chondroitinase $\mathrm{ABC}$ in the sub-acute stage promotes axonal outgrowth and functional recovery after complete spinal cord transection PLoS One, 10 (2015), Article e0138705

Dou and Levine, 1994 C.L. Dou, J.M. Levine Inhibition of neurite growth by the NG2 chondroitin sulfate proteoglycan J. Neurosci., 14 (1994), pp. 7616-7628

Fouad et al., 2005 K. Fouad, L. Schnell, M.B. Bunge, M.E. Schwab, T. Liebscher, D.D. Pearse Combining Schwann cell bridges and olfactory-ensheathing glia grafts with chondroitinase promotes locomotor recovery after complete transection of the spinal cord J. Neurosci., 25 (2005), pp. 1169-1178

Garcia-Alias et al., 2009 G. Garcia-Alias, S. Barkhuysen, M. Buckle, J.W. Fawcett Chondroitinase ABC treatment opens a window of opportunity for task-specific rehabilitation Nat. Neurosci., 12 (2009), pp. 1145-1151

Geeven et al., 2011 G. Geeven, H.D. Macgillavry, R. Eggers, M.M. Sassen, J. Verhaagen, A.B. Smit, M.C. de Gunst, R.E. van Kesteren LLM3D: a log-linear modeling-based method to predict functional gene regulatory interactions from genome-wide expression data Nucleic Acids Res., 39 (2011), pp. 5313-5327

Hollis et al., 2009 E.R. Hollis 2nd, P. Lu, A. Blesch, M.H. Tuszynsk iIGF-I gene delivery promotes corticospinal neuronal survival but not regeneration after adult CNS injury Exp. Neurol., 215 (2009), pp. 53-59

Howell et al., 2015 M.D. Howell, L.A. Bailey, M.A. Cozart, B.M. Gannon, P.E. Gottschall Hippocampal administration of chondroitinase $\mathrm{ABC}$ increases plaque-adjacent synaptic marker and diminishes amyloid burden in aged APPswe/PS1dE9 mice Acta Neuropathol Commun., 3 (2015), p. 54

Hunanyan et al., 2013 A.S. Hunanyan, H.A. Petrosyan, V. Alessi, V.L. Arvanian Combination of chondroitinase $\mathrm{ABC}$ and AAV-NT3 promotes neural plasticity at descending spinal pathways after thoracic contusion in rats J. Neurophysiol., 110 (2013), pp. 1782-1792

Iseda et al., 2008 T. Iseda, T. Okuda, N. Kane-Goldsmith, M. Mathew, S. Ahmed, Y.W. Chang, W. Young, M. Grumet Single, high-dose intraspinal injection of chondroitinase reduces glycosaminoglycans in

Neurobiology of Disease, Vol. 99 (March 2017): pg. 24-35. DOI. This article is @ Elsevier and permission has been granted for this version to appear in e-Publications@Marquette. Elsevier does not grant permission for this article to be further copied/distributed or hosted elsewhere without the express permission from Elsevier. 
NOT THE PUBLISHED VERSION; this is the author's final, peer-reviewed manuscript. The published version may be accessed by following the link in the citation at the bottom of the page.

injured spinal cord and promotes corticospinal axonal regrowth after hemisection but not contusion J. Neurotrauma, 25 (2008), pp. 334-349

Łankowski et al., 2009 M.P. Jankowski, S.L. Mcllwrath, X. Jing, P.K. Cornuet, K.M. Salerno, H.R. Koerber, K.M. Albers Sox11 transcription factor modulates peripheral nerve regeneration in adult mice Brain Res., 1256 (2009), pp. 43-54

ذin et al., 2011 Y. Jin, A. Ketschek, Z. Jiang, G. Smith, I. Fischer Chondroitinase activity can be transduced by a lentiviral vector in vitro and in vivo J. Neurosci. Methods, 199 (2011), pp. 208-213

Jones et al., 2003 L.L. Jones, R.U. Margolis, M.H. Tuszynski The chondroitin sulfate proteoglycans neurocan, brevican, phosphacan, and versican are differentially regulated following spinal cord injury Exp. Neurol., 182 (2003), pp. 399-411

Jones et al., 2002 L.L. Jones, Y. Yamaguchi, W.B. Stallcup, M.H. Tuszynski NG2 is a major chondroitin sulfate proteoglycan produced after spinal cord injury and is expressed by macrophages and oligodendrocyte progenitors J. Neurosci., 22 (2002), pp. 2792-2803

Kanno et al., 2014 H. Kanno, Y. Pressman, A. Moody, R. Berg, E.M. Muir, J.H. Rogers, H. Ozawa, E. Itoi, D.D. Pearse, M.B. Bunge Combination of engineered Schwann cell grafts to secrete neurotrophin and chondroitinase promotes axonal regeneration and locomotion after spinal cord injury J. Neurosci., 34 (2014), pp. 1838-1855

Kerschensteiner et al., 2005 M. Kerschensteiner, M.E. Schwab, J.W. Lichtman, T. Misgeld In vivo imaging of axonal degeneration and regeneration in the injured spinal cord Nat. Med., 11 (2005), pp. 572577

Kwok et al., 2008 J.C. Kwok, F. Afshari, G. Garcia-Alias, J.W. Fawcett Proteoglycans in the central nervous system: plasticity, regeneration and their stimulation with chondroitinase ABC Restor. Neurol. Neurosci., 26 (2008), pp. 131-145

Laub et al., 2001 F. Laub, R. Aldabe, V. Friedrich Jr., S. Ohnishi, T. Yoshida, F. Ramirez Developmental expression of mouse Kruppel-like transcription factor KLF7 suggests a potential role in neurogenesis Dev. Biol., 233 (2001), pp. 305-318

Lee et al., 2010b J.K. Lee, C.G. Geoffroy, A.F. Chan, K.E. Tolentino, M.J. Crawford, M.A. Leal, B. Kang, B. Zheng Assessing spinal axon regeneration and sprouting in Nogo-, MAG-, and OMgp-deficient mice Neuron, 66 (2010), pp. 663-670

Lee et al., 2013 Y.S. Lee, C.Y. Lin, H.H. Jiang, M. Depaul, V.W. Lin, J. Silver Nerve regeneration restores supraspinal control of bladder function after complete spinal cord injury J. Neurosci., 33 (2013), pp. 10591-10606

Lee et al., 2014 D.H. Lee, X. Luo, B.J. Yungher, E. Bray, J.K. Lee, K.K. Park Mammalian target of rapamycin's distinct roles and effectiveness in promoting compensatory axonal sprouting in the injured CNS $J$. Neurosci., 34 (2014), pp. 15347-15355

Lee et al., 2010a H. Lee, R.J. McKeon, R.V. Bellamkonda Sustained delivery of thermostabilized chABC enhances axonal sprouting and functional recovery after spinal cord injury Proc. Natl. Acad. Sci. U. S. A., 107 (2010), pp. 3340-3345

Liu et al., 2011 K. Liu, A. Tedeschi, K.K. Park, Z. He Neuronal intrinsic mechanisms of axon regeneration Annu. Rev. Neurosci., 34 (2011), pp. 131-152

Ma and Willis, 2015 T.C. Ma, D.E. Willis What makes a RAG regeneration associated? Front. Mol. Neurosci., 8 (2015), p. 43

Neurobiology of Disease, Vol. 99 (March 2017): pg. 24-35. DOI. This article is @ Elsevier and permission has been granted for this version to appear in e-Publications@Marquette. Elsevier does not grant permission for this article to be further copied/distributed or hosted elsewhere without the express permission from Elsevier. 
NOT THE PUBLISHED VERSION; this is the author's final, peer-reviewed manuscript. The published version may be accessed by following the link in the citation at the bottom of the page.

Mason et al., 2003 M.R. Mason, A.R. Lieberman, P.N. Anderson Corticospinal neurons up-regulate a range of growth-associated genes following intracortical, but not spinal, axotomy Eur. J. Neurosci., 18 (2003), pp. 789-802

Mauney et al., 2013 S.A. Mauney, K.M. Athanas, H. Pantazopoulos, N. Shaskan, E. Passeri, S. Berretta, T.U. Woo Developmental pattern of perineuronal nets in the human prefrontal cortex and their deficit in schizophrenia Biol. Psychiatry, 74 (2013), pp. 427-435

Michaelevski et al., 2010 I. Michaelevski, Y. Segal-Ruder, M. Rozenbaum, K.F. Medzihradszky, O. Shalem, G. Coppola, S. Horn-Saban, K. Ben-Yaakov, S.Y. Dagan, I. Rishal, D.H. Geschwind, Y. Pilpel, A.L. Burlingame, M. Fainzilber Signaling to transcription networks in the neuronal retrograde injury response Sci. Signal., 3 (2010), p. ra53

Moore and Goldberg, 2011 D.L. Moore, J.L. Goldberg Multiple transcription factor families regulate axon growth and regeneration Dev Neurobiol., 71 (2011), pp. 1186-1211

Moore et al., 2009 D.L. Moore, M.G. Blackmore, Y. Hu, K.H. Kaestner, J.L. Bixby, V.P. Lemmon, J.L. Goldberg KLF family members regulate intrinsic axon regeneration ability Science, 326 (2009), pp. 298301

Muir et al., 2010 E.M. Muir, I. Fyfe, S. Gardiner, L. Li, P. Warren, J.W. Fawcett, R.J. Keynes, J.H. Rogers Modification of N-glycosylation sites allows secretion of bacterial chondroitinase $\mathrm{ABC}$ from mammalian cells J. Biotechnol., 145 (2010), pp. 103-110

Nazari-Robati et al., 2013 M. Nazari-Robati, K. Khajeh, M. Aminian, N. Mollania, A. Golestani Enhancement of thermal stability of chondroitinase ABC I by site-directed mutagenesis: an insight from Ramachandran plot Biochim. Biophys. Acta, 1834 (2013), pp. 479-486

Niederost et al., 1999 B.P. Niederost, D.R. Zimmermann, M.E. Schwab, C.E. Bandtlow Bovine CNS myelin contains neurite growth-inhibitory activity associated with chondroitin sulfate proteoglycans $J$. Neurosci., 19 (1999), pp. 8979-8989

Parikh et al., 2011 P. Parikh, Y. Hao, M. Hosseinkhani, S.B. Patil, G.W. Huntley, M. Tessier-Lavigne, H. Zou Regeneration of axons in injured spinal cord by activation of bone morphogenetic protein/Smad1 signaling pathway in adult neurons Proc. Natl. Acad. Sci. U. S. A., 108 (2011), pp. E99-107

Pearse et al., 2004 D.D. Pearse, F.C. Pereira, A.E. Marcillo, M.L. Bates, Y.A. Berrocal, M.T. Filbin, M.B. Bungec AMP and Schwann cells promote axonal growth and functional recovery after spinal cord injury Nat. Med., 10 (2004), pp. 610-616

Richardson et al., 1984 P.M. Richardson, V.M. Issa, A.J. Aguayo Regeneration of long spinal axons in the rat J. Neurocytol., 13 (1984), pp. 165-182

Schmalfeldt et al., 2000 M. Schmalfeldt, C.E. Bandtlow, M.T. Dours-Zimmermann, K.H. Winterhalter, D.R. Zimmermann Brain derived versican V2 is a potent inhibitor of axonal growth J. Cell Sci., 113 (Pt 5) (2000), pp. 807-816

Shields et al., 2008 L.B. Shields, Y.P. Zhang, D.A. Burke, R. Gray, C.B. Shields Benefit of chondroitinase ABC on sensory axon regeneration in a laceration model of spinal cord injury in the rat Surg. Neurol., 69 (2008), pp. 568-577 (discussion 577)

Silver and Miller, 2004 J. Silver, J.H. Miller Regeneration beyond the glial scar Nat. Rev. Neurosci., 5 (2004), pp. 146-156

Smith and Skene, 1997 D.S. Smith, J.H. Skene A transcription-dependent switch controls competence of adult neurons for distinct modes of axon growth J. Neurosci., 17 (1997), pp. 646-658

Neurobiology of Disease, Vol. 99 (March 2017): pg. 24-35. DOI. This article is @ Elsevier and permission has been granted for this version to appear in e-Publications@Marquette. Elsevier does not grant permission for this article to be further copied/distributed or hosted elsewhere without the express permission from Elsevier. 
NOT THE PUBLISHED VERSION; this is the author's final, peer-reviewed manuscript. The published version may be accessed by following the link in the citation at the bottom of the page.

Snow et al., 1996 D.M. Snow, E.M. Brown, P.C. Letourneau Growth cone behavior in the presence of soluble chondroitin sulfate proteoglycan (CSPG), compared to behavior on CSPG bound to laminin or fibronectin Int. J. Dev. Neurosci., 14 (1996), pp. 331-349

Snow et al., 1990 D.M. Snow, V. Lemmon, D.A. Carrino, A.I. Caplan, J. Silver Sulfated proteoglycans in astroglial barriers inhibit neurite outgrowth in vitro Exp. Neurol., 109 (1990), pp. 111-130

Soleman et al., 2012 S. Soleman, P.K. Yip, D.A. Duricki, L.D. Moon Delayed treatment with chondroitinase ABC promotes sensorimotor recovery and plasticity after stroke in aged rats Brain, 135 (2012), pp. $1210-1223$

Stam et al., 2007 F.J. Stam, H.D. MacGillavry, N.J. Armstrong, M.C. de Gunst, Y. Zhang, R.E. van Kesteren, A.B. Smit, J. Verhaagen Identification of candidate transcriptional modulators involved in successful regeneration after nerve injury Eur. J. Neurosci., 25 (2007), pp. 3629-3637

Starkey et al., 2012 M.L. Starkey, K. Bartus, A.W. Barritt, E.J. Bradbury Chondroitinase ABC promotes compensatory sprouting of the intact corticospinal tract and recovery of forelimb function following unilateral pyramidotomy in adult mice Eur. J. Neurosci., 36 (2012), pp. 3665-3678

Steinmetz et al., 2005 M.P. Steinmetz, K.P. Horn, V.J. Tom, J.H. Miller, S.A. Busch, D. Nair, D.J. Silver, J. Silver Chronic enhancement of the intrinsic growth capacity of sensory neurons combined with the degradation of inhibitory proteoglycans allows functional regeneration of sensory axons through the dorsal root entry zone in the mammalian spinal cord J. Neurosci., 25 (2005), pp. 8066-8076

Tom et al., 2009 V.J. Tom, H.R. Sandrow-Feinberg, K. Miller, L. Santi, T. Connors, M.A. Lemay, J.D. Houle Combining peripheral nerve grafts and chondroitinase promotes functional axonal regeneration in the chronically injured spinal cord J. Neurosci., 29 (2009), pp. 14881-14890

Tom et al., 2004 V.J. Tom, M.P. Steinmetz, J.H. Miller, C.M. Doller, J. Silver Studies on the development and behavior of the dystrophic growth cone, the hallmark of regeneration failure, in an in vitro model of the glial scar and after spinal cord injury J. Neurosci., 24 (2004), pp. 6531-6539

Tropea et al., 2003 D. Tropea, M. Caleo, L. Maffei Synergistic effects of brain-derived neurotrophic factor and chondroitinase $\mathrm{ABC}$ on retinal fiber sprouting after denervation of the superior colliculus in adult rats J. Neurosci., 23 (2003), pp. 7034-7044

Tsujino et al., 2000 H. Tsujino, E. Kondo, T. Fukuoka, Y. Dai, A. Tokunaga, K. Miki, K. Yonenobu, T. Ochi, K. Noguchi Activating transcription factor 3 (ATF3) induction by axotomy in sensory and motoneurons: a novel neuronal marker of nerve injury Mol. Cell. Neurosci., 15 (2000), pp. 170182

Tuszynski and Steward, 2012 M.H. Tuszynski, O. Steward Concepts and methods for the study of axonal regeneration in the CNS Neuron, 74 (2012), pp. 777-791

Usher et al., 2010 L.C. Usher, A. Johnstone, A. Erturk, Y. Hu, D. Strikis, I.B. Wanner, S. Moorman, J.W. Lee, J. Min, H.H. Ha, Y. Duan, S. Hoffman, J.L. Goldberg, F. Bradke, Y.T. Chang, V.P. Lemmon, J.L. Bixby A chemical screen identifies novel compounds that overcome glial-mediated inhibition of neuronal regeneration J. Neurosci., 30 (2010), pp. 4693-4706

van Kesteren et al., 2011 R.E. van Kesteren, M.R. Mason, H.D. Macgillavry, A.B. Smit, J. Verhaagen A gene network perspective on axonal regeneration Front. Mol. Neurosci., 4 (2011), p. 46

Veldman et al., 2007 M.B. Veldman, M.A. Bemben, R.C. Thompson, D. Goldman Gene expression analysis of zebrafish retinal ganglion cells during optic nerve regeneration identifies KLF6a and KLF7a as important regulators of axon regeneration Dev. Biol., 312 (2007), pp. 596-612

Neurobiology of Disease, Vol. 99 (March 2017): pg. 24-35. DOI. This article is @ Elsevier and permission has been granted for this version to appear in e-Publications@Marquette. Elsevier does not grant permission for this article to be further copied/distributed or hosted elsewhere without the express permission from Elsevier. 
NOT THE PUBLISHED VERSION; this is the author's final, peer-reviewed manuscript. The published version may be accessed by following the link in the citation at the bottom of the page.

Vulchanova et al., 2010 L. Vulchanova, D.J. Schuster, L.R. Belur, M.S. Riedl, K.M. Podetz-Pedersen, K.F. Kitto, G.L. Wilcox, R.S. McIvor, C.A. Fairbanks Differential adeno-associated virus mediated gene transfer to sensory neurons following intrathecal delivery by direct lumbar puncture Mol. Pain, 6 (2010), p. 31

Wang et al., 2011 D. Wang, R.M. Ichiyama, R. Zhao, M.R. Andrews, J.W. Fawcett Chondroitinase combined with rehabilitation promotes recovery of forelimb function in rats with chronic spinal cord injury J. Neurosci., 31 (2011), pp. 9332-9344

Wang et al., 2015 Z. Wang, A. Reynolds, A. Kirry, C. Nienhaus, M.G. Blackmore Overexpression of Sox11 promotes corticospinal tract regeneration after spinal injury while interfering with functional recovery J. Neurosci., 35 (2015), pp. 3139-3145

Yamada et al., 1997 H. Yamada, B. Fredette, K. Shitara, K. Hagihara, R. Miura, B. Ranscht, W.B. Stallcup, Y. Yamaguchi The brain chondroitin sulfate proteoglycan brevican associates with astrocytes ensheathing cerebellar glomeruli and inhibits neurite outgrowth from granule neurons $J$. Neurosci., 17 (1997), pp. 7784-7795

Zhang et al., 2004 Y.P. Zhang, C. Iannotti, L.B. Shields, Y. Han, D.A. Burke, X.M. Xu, C.B. Shields Dural closure, cord approximation, and clot removal: enhancement of tissue sparing in a novel laceration spinal cord injury model J. Neurosurg., 100 (2004), pp. 343-352

Zhao et al., 2011 R.R. Zhao, E.M. Muir, J.N. Alves, H. Rickman, A.Y. Allan, J.C. Kwok, K.C. Roet, J. Verhaagen, B.L. Schneider, J.C. Bensadoun, S.G. Ahmed, R.J. Yanez-Munoz, R.J. Keynes, J.W. Fawcett, J.H. Rogers Lentiviral vectors express chondroitinase $\mathrm{ABC}$ in cortical projections and promote sprouting of injured corticospinal axons J. Neurosci. Methods, 201 (2011), pp. 228-238

Neurobiology of Disease, Vol. 99 (March 2017): pg. 24-35. DOI. This article is (C) Elsevier and permission has been granted for this version to appear in e-Publications@Marquette. Elsevier does not grant permission for this article to be further copied/distributed or hosted elsewhere without the express permission from Elsevier. 